Check for updates

Cite this: RSC Adv., 2020, 10, 12554

\title{
Anammox and partial denitrification coupling: a review
}

\author{
Qing-Guo You, abc Jian-Hui Wang, (D) abc Gao-Xiang Qi, ${ }^{\text {ab }}$ Yue-Ming Zhou, ${ }^{\text {ab }}$ \\ Zhi-Wei Guo, (D) ab Yu Shen*abc and Xu Gao*ab
}

As a new wastewater biological nitrogen removal process, anammox and partial denitrification coupling not only plays a significant role in the nitrogen cycle, but also holds high engineering application value. Because anammox and some denitrifying bacteria are coupled under harsh living conditions, certain operating conditions and mechanisms of the coupling process are not clear; thus, it is more difficult to control the process, which is why the process has not been widely applied. This paper analyzes the research focusing on the coupling process in recent years, including anammox and partial denitrification coupling process inhibitors such as nitrogen $\left(\mathrm{NH}_{4}{ }^{+}, \mathrm{NO}_{2}{ }^{-}\right)$, organics (toxic and non-toxic organics), and salts. The mechanism of substrate removal in anammox and partial denitrification coupling nitrogen removal is described in detail. Due to the differences in process methods, experimental conditions, and sludge choices between the rapid start-up and stable operation stages of the reactor, there are significant differences in substrate inhibition. Multiple process parameters (such as $\mathrm{pH}$, temperature, dissolved oxygen, redox potential, carbon-to-nitrogen ratio, and sludge) can be adjusted to improve the coupling of anammox and partial denitrification to modify nitrogen removal performance.

Received 1st January 2020

Accepted 12th March 2020

DOI: $10.1039 / \mathrm{dOra00001a}$

rsc.li/rsc-advances

same time. In one case, a novel partial denitrification anammox coupling process achieved a high total nitrogen (TN) removal rate of $97.8 \% .^{3}$ The development of the anammox and partial denitrification coupling technology shows great significance for

With the development of the economy and public awareness of environmental protection, the pollution of water environments has become the central topic of academic discussion. The deterioration of water quality caused by the accumulation of inorganic nitrogen is a typical and serious pollution source, and it can influence human and animal health directly or indirectly. ${ }^{1,2}$ In recent years, high nitrogen removal has been a focus point in water treatment. $\mathrm{NO}_{3}{ }^{-}, \mathrm{NO}_{2}{ }^{-}$and $\mathrm{NH}_{4}{ }^{+}$are the main living style of the cycle network of inorganic nitrogen in the biosphere (Fig. 1) in nature. Nitrogen removal in sewage treatment means that different forms of nitrogen are converted into nitrogen and discharged into air. Familiar nitrogen removal processes include nitrification and denitrification, partial nitrification and denitrification, the anammox process, and the anammox and partial denitrification coupling process. In these processes, anammox and partial denitrification coupling is a clean and environment-friendly approach, which can remove ammonia nitrogen, nitrate nitrogen and nitrous nitrogen at the

${ }^{a}$ National Research Base of Intelligent Manufacturing Service, Chongqing Technology and Business University, Chongqing 400067, China. E-mail: shenyu@ctbu.edu.cn; hughgao@outlook.com; Fax: +86 23 62768039; Tel: +86 2362768039

${ }^{b}$ Chongqing South-to-Thais Environmental Protection Technology Research Institute Co., Ltd., Chongqing 400069, China

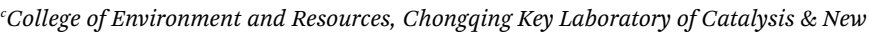
Environmental Materials, Chongqing Technology and Business University, Chongqing 400067, China

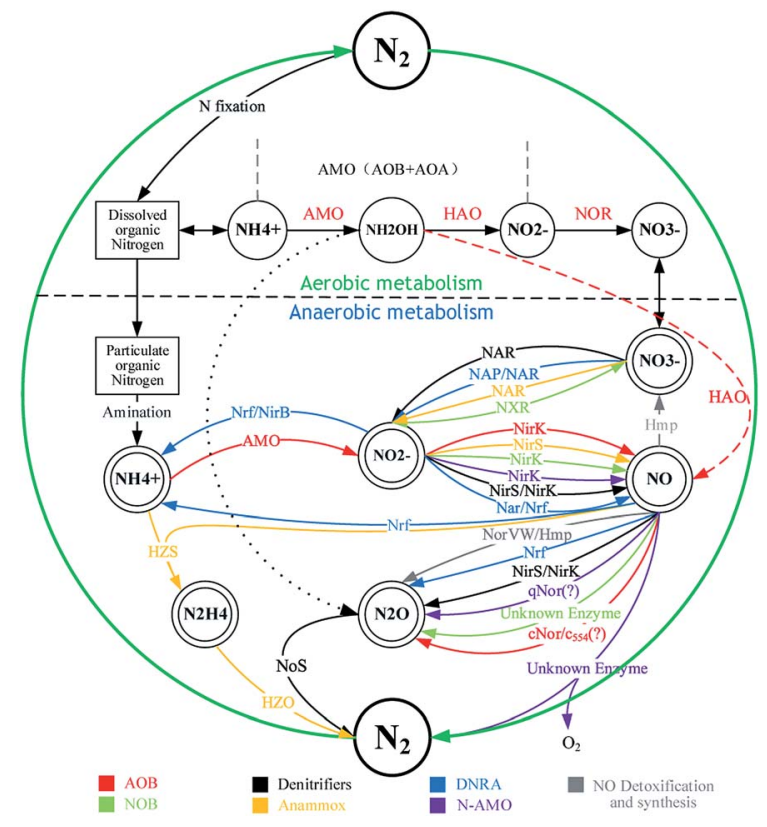

Fig. 1 Nitrogen biosphere cycle network. 
the establishment of a relatively complete denitrification mechanism and a new nitrogen cycle system. ${ }^{4}$ The coupling mechanism is shown in Fig. 2: (1) Denitrification provides carbon sources and substrates for anammox. During the denitrification process, $\mathrm{NO}_{3}{ }^{-}$, as an electron acceptor, generates $\mathrm{NO}_{2}{ }^{-}$under enzymatic action and inhibits $\mathrm{NO}_{2}{ }^{-}$reductase to reduce $\mathrm{N}_{2} \mathrm{O}$ production, where organic matter is consumed and $\mathrm{CO}_{2}$ is generated. ${ }^{2,5}$ (2) Partial denitrification consumes dissolved oxygen (DO) during the consumption of organic matter to provide a low-oxygen environment for anammox; ${ }^{6} \mathrm{CO}_{2}$ from denitrification is used as a carbon source for anammox. (3) Anammox consumes the substrate $\mathrm{NO}_{2}{ }^{-}$, reducing the effects of $\mathrm{NO}_{2}{ }^{-}$accumulation on denitrification and avoiding the further reduction of $\mathrm{NO}_{2}{ }^{-}$to $\mathrm{N}_{2} \mathrm{O}$. Anammox bacteria use $\mathrm{NO}_{2}{ }^{-}$and $\mathrm{NH}_{4}{ }^{+}$as substrates that are reduced and oxidized to $\mathrm{N}_{2}$, and the released energy is used for $\mathrm{CO}_{2}$ synthesis of organic matter and life activities. ${ }^{7,8}$

In 1998, Strous et al. ${ }^{9}$ cultivated anammox bacteria in a sequencing batch reactor and proposed a stoichiometric formula for the anammox metabolism (eqn (1)). Although many quantitative methods of anammox metabolism have been proposed in recent years, such as that by Lotti et al.,${ }^{\mathbf{1 0}}$ the growth mechanism of suspension of anammox bacteria and the study of the kinetics of eqn (2) and (1) have a wide range of applications and are readily accepted by scholars.

$$
\begin{aligned}
& \mathrm{NH}_{4}{ }^{+}+1.32 \mathrm{NO}_{2}{ }^{-}+0.66 \mathrm{HCO}_{3}{ }^{-}+0.13 \mathrm{H}^{+} \rightarrow \\
& 0.066 \mathrm{CH}_{2} \mathrm{O}_{0.5} \mathrm{~N}_{0.15}+1.02 \mathrm{~N}_{2}+0.26 \mathrm{NO}_{3}{ }^{-}+2.03 \mathrm{H}_{2} \mathrm{O} \\
& \mathrm{NH}_{4}{ }^{+}+1.146 \mathrm{NO}_{2}{ }^{-}+0.071 \mathrm{HCO}_{3}{ }^{-}+0.057 \mathrm{H}^{+} \rightarrow \\
& 0.071 \mathrm{CH}_{1.74} \mathrm{O}_{0.31} \mathrm{~N}_{0.20}+0.986 \mathrm{~N}_{2}+0.161 \mathrm{NO}_{3}{ }^{-}+2.0002 \mathrm{H}_{2} \mathrm{O} \\
& \mathrm{NO}_{3}{ }^{-}+0.083 \mathrm{C}_{6} \mathrm{H}_{12} \mathrm{O}_{6} \rightarrow \mathrm{NO}_{2}{ }^{-}+0.5 \mathrm{CO}_{2}+0.5 \mathrm{H}_{2} \mathrm{O}
\end{aligned}
$$
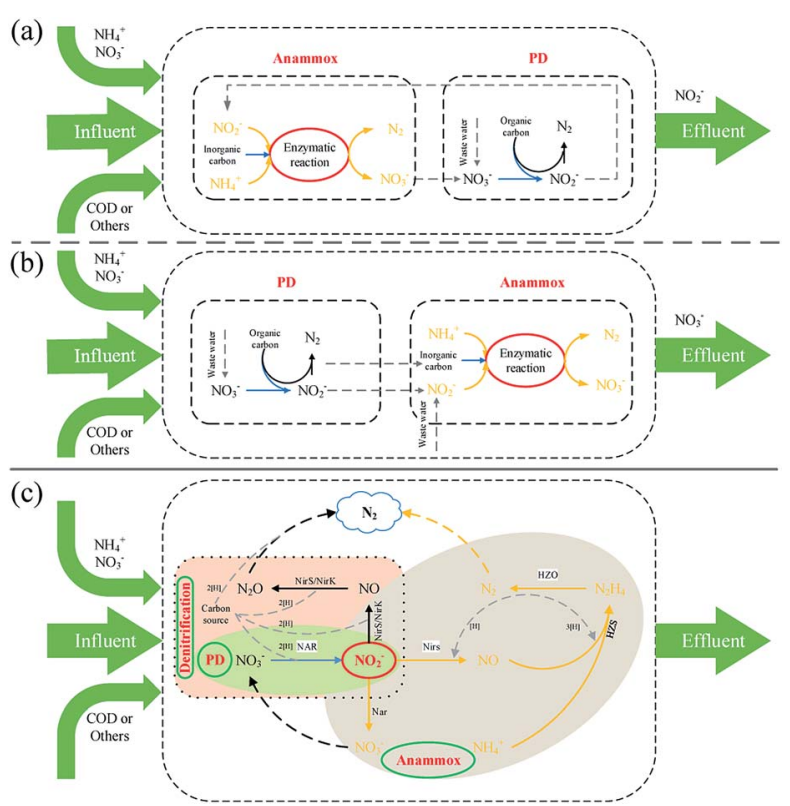

Fig. 2 Anammox and partial denitrification coupling nitrogen removal matrix flow direction.
As shown by eqn (1) and (2), $\mathrm{NO}_{3}{ }^{-}$produces about $11.2 \%$ of the total nitrogen after consuming $1 \mathrm{~mol}$ of $\mathrm{NH}_{4}{ }^{+}$. Although nitrogen in sewage cannot be eliminated, it supplements the consumption of $\mathrm{NO}_{3}{ }^{-}$in the denitrification process. ${ }^{6}$ Therefore, the operating costs of wastewater treatment plants (WWTPs) are reduced. ${ }^{11-14}$ Through the anammox and partial denitrification coupling process, the $\mathrm{NO}_{3}{ }^{-}-\mathrm{N}$ removal efficiency can reach 95.8\%, while the $\mathrm{NH}_{4}{ }^{+}-\mathrm{N}$ removal rate reaches $92.8 \%$ and the anammox contribution to TN removal is $78.9 \% .^{13}$ The process meets the requirements of smaller space, simple control and environmental friendliness; furthermore, it creates no secondary pollution. ${ }^{7}$

\section{Anammox and partial denitrification coupling process and application}

Anammox and partial denitrification coupling nitrogen removal is divided into separated and combined processes (Table 1).

\subsection{Separated process}

The separated process of anammox and partial denitrification coupling is inoculated with denitrifying bacteria and anammox with absolute advantages in two mutually independent reactors and simultaneously generates $\mathrm{NO}_{2}{ }^{-}-\mathrm{N}$ and nitrogen removal processes, which can effectively avoid space competition. Organic matter is fully utilized by denitrifying bacteria in the denitrification reactor, reducing the concentration of organic matter flowing to the anammox reactor. Wastewater containing nitrate (such as municipal wastewater, industrial wastewater, and aquaculture wastewater) first flowed into the partial denitrification reactor to reduce nitrate to $\mathrm{NO}_{2}{ }^{-}-\mathrm{N}$ while consuming organic matter as the electron donor. Then, the wastewater $\mathrm{NO}_{2}{ }^{-}$was adjusted before flowing into the anammox reactor $\left(\mathrm{NO}_{2}{ }^{-}-\mathrm{N} / \mathrm{NH}_{4}{ }^{+}-\mathrm{N}=1.32\right)$ and was used to remove nitrogen, and part of the effluent returned to the partial denitrification reactor for deep nitrogen removal. ${ }^{13}$

Cao et al. ${ }^{15}$ used a separated reactor to treat highconcentration nitrogen-containing wastewater $\left(\mathrm{NO}_{3}{ }^{-}-\mathrm{N}=\right.$ $820 \mathrm{mg} \mathrm{L}^{-1}$ ) in which the TN in the effluent was less than $20 \mathrm{mg} \mathrm{L}^{-1}$, and the TN removal rate was as high as $97.8 \%$. It is demonstrated that the removal rate of $\mathrm{NH}_{4}{ }^{+}-\mathrm{N}$ peaks at $96.7 \%$ when treating domestic sewage, and this process can effectively solve the problem of nitrogen residues in sewage. Du et al. ${ }^{\mathbf{1 3}}$ optimized the mixed volume ratio of influent $\mathrm{NO}_{3}{ }^{-}-\mathrm{N}$ and sewage and the amount of organic matter to treat high-nitrogen wastewater $\left(\mathrm{NO}_{3}{ }^{-}-\mathrm{N}=1000 \mathrm{mg} \mathrm{L}^{-1}\right)$; the $\mathrm{TN}$ in the effluent was less than $11 \mathrm{mg} \mathrm{L}^{-1}$, and the removal rate of TN was as high as 95.8\%. Meanwhile, the contribution rate of anammox to TN nitrogen removal was $78.9 \%$. In addition, Wang et al. ${ }^{\mathbf{1 6}}$ proposed a new process, EPDPR (endogenous partial denitrification and denitrifying phosphorus removal), in which the removal rate of phosphorus is as high as $92.3 \%$ and the output of $79.2 \%$ of $\mathrm{NO}_{2}{ }^{-}-\mathrm{N}$ is the best for the post-anammox process. The suitable substrate ratio $\left(\mathrm{NO}_{2}{ }^{-}-\mathrm{N} / \mathrm{NH}_{4}{ }^{+}-\mathrm{N}=1.32\right)$ and high purification capacity $\left(\mathrm{TN}<6 \mathrm{mg} \mathrm{L}^{-1}, \mathrm{TP}<0.4 \mathrm{mg} \mathrm{L}^{-1}\right)$ provide new ideas for removing nitrogen, phosphorus and other 


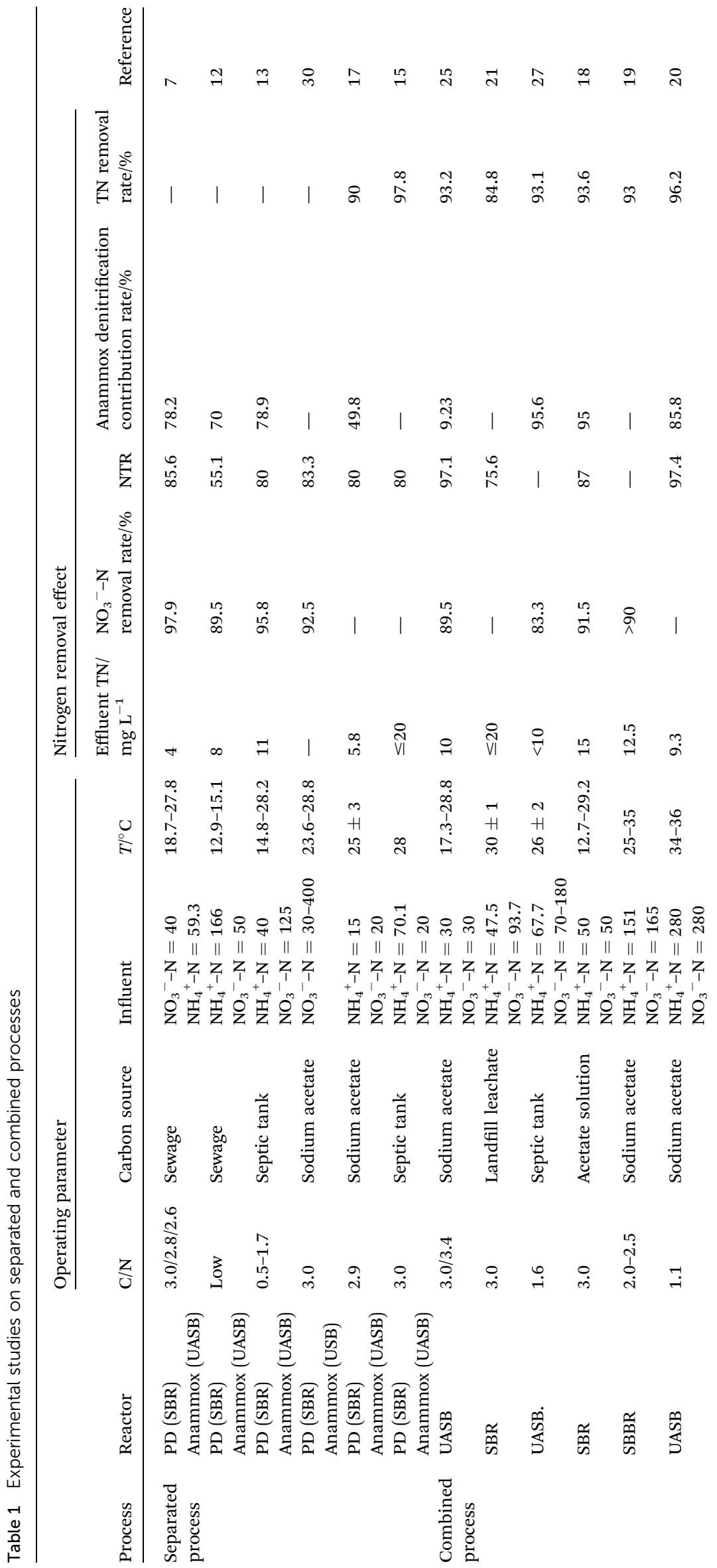


nutrients from sewage. A mainstream literature search showed that the reason why the separated process is stable and the TN removal rate is high is that anammox makes a greater contribution to the TN removal rate. ${ }^{7,12,13,17}$

\subsection{Combined process}

The combined process of anammox and partial denitrification coupling is started by inoculating the optimal partial denitrification floc sludge and anammox granular sludge, ${ }^{18-20}$ and it has also been reported that the inoculated partial denitrification sludge is acclimated from PN sludge. ${ }^{21}$

Zhang et al. $^{\mathbf{2 0}}$ reported a new process called completely anaerobic ammonium removal over nitrite (CAARON); they compared the simultaneous addition of acetate at low $\mathrm{C} / \mathrm{N}$ with that of asynchronous addition and confirmed that the asynchronous addition of acetate optimized the reactor. The distribution of the bacterial nitrate-to-nitrite transformation ratio (NTR) was $97.4 \%$, and the anammox nitrogen removal contribution rate was $85.8 \%$. Also, Du et al. ${ }^{22}$ carried out the DEAMOX reaction in an SBR reactor, and supplying acetate to the reactor at different periods also achieved a nitrogen removal rate of up to $95.8 \%$. Zhang et $a .^{23}$ studied the engineering feasibility, economic feasibility, and potential challenges of the PN/AMX and PDN/AMX processes. The researchers noted that bacteria showed good capture of soluble COD; this is another way to control the effects of organic matter on anammox bacteria. Qin et $a .^{24}$ focused on the effects of glucose on DEAMXO nitrogen removal performance in an upstream continuous consideration reactor and confirmed that dissolved COD had a significant effect on the biological communities. When the concentration of glucose was $56.4 \mathrm{mg} \mathrm{L}^{-1}$, the system $\mathrm{TN}$ removal rate was $98.6 \%$.

\subsection{Reactor management}

The method of managing the reactor in the separated and combined processes is as follows:

(1) Selection of reactor type and seed sludge. Given that the processing has low carbon demand and minimal sludge production, researchers usually use SBR or UASB as the anammox and partial denitrification coupling starting reactor. ${ }^{18,20,21,25}$ Anammox granular sludge and partial denitrification floc sludge are inoculated as seed sludge, or anammox sludge is domesticated to obtain the target strain.

(2) Optimization of hydraulic retention time (HRT) and proper ventilation. Properly increasing wastewater HRT in the reactor can afford higher TN and COD removal rates, and even difficult-to-degrade COD will be consumed in a higher HRT. This method effectively enriches a sufficient amount of partial denitrification and anammox functional microorganisms. ${ }^{\mathbf{1 3 , 1 9 , 2 5}}$ Optimizing aeration can avoid excessive production of extracellular polymers (EPS), which is beneficial to the stability of the microbial community and nitrogen removal. ${ }^{25}$

(3) Selection of organic matter feeding methods and addition of microbial carriers. Organic matter feeding methods are distributed continuously and intermittently. The richness and metabolism of continuous feeding of organic matter anammox bacteria will be limited, reducing the nitrogen removal ability of the reactor. Intermittent feeding is widely used in the combined process and performs well, with a high TN load nitrogen removal effect. ${ }^{20,22}$ Partial denitrification and anammox bacteria can be effectively retained on the microbial carrier, expand the specific surface area of the microorganism, increase the mass transfer rate, and enhance the nitrogen removal effect. ${ }^{26,27}$

\subsection{Engineering application}

Research of the anammox and partial denitrification coupling process is still in its infancy. The process has not been popularized or applied to nitrogen removal for municipal wastewater treatment; therefore, it has been rarely reported to date. Although the engineering application of anammox has been increasing gradually in the past 10 years, the development of anammox and some denitrification coupling processes have lagged, and laboratory-scale research $\mathrm{h}^{7,13,25,28}$ has a positive effect on engineering applications.

Wang et al. $^{29}$ reported simultaneous partial nitrification, anaerobic ammonium oxidation and denitrification (SNAD) treatment of landfill leachate in a full-scale $\left(192 \mathrm{~m}^{3}\right)$ sewage treatment plant. The TN removal was around $83.9 \%$, which confirms that mass balance of the system is the best approach for the evaluation of anammox and nitration processes and that molecular tools and tracer studies with labeled nitrogen are useful approaches for the evaluation of anammox. Based on an AAO process, Li et al. ${ }^{26}$ added carriers to the reactor to enrich anammox bacteria in the anoxic zone, forming the An-AAO process. Anammox species enrichment in situ increases the nitrogen removal rate, and it has been proven that anammox has a high nitrogen removal contribution rate and is the key to the stability and engineering application of the denitrification coupling process, which was successfully used in urban sewage treatment plants.

\section{Inhibition factors of the coupling process}

\subsection{Nitrogen inhibition}

$\mathrm{NH}_{4}{ }^{+}, \mathrm{NO}_{2}{ }^{-}$and $\mathrm{NO}_{3}{ }^{-}$are important monitoring indicators of wastewater (including domestic sewage, landfill leachate, mustard wastewater, aquaculture wastewater and printing and dyeing wastewater). $\mathrm{NO}_{2}{ }^{-}$and $\mathrm{NO}_{3}{ }^{-}$act as key raw materials and inhibitors in the anammox and partial denitrification coupling process. Their inhibition mechanism and concentration will affect the coupling process, operating conditions and operating strategies; therefore, it is imperative to understand the nitrogen inhibitory concentration and mechanism.

3.1.1 Free ammonia inhibition. One study found that a high concentration of $\mathrm{NH}_{4}{ }^{+}$has no influence on the anammox process; Strous et al. ${ }^{31}$ noted that the anammox process showed no inhibition when treating high-concentration ammonia nitrogen wastewater at $1000 \mathrm{mg} \mathrm{L^{-1 }} \mathrm{NH}_{4}{ }^{+}$. Isaka et al. ${ }^{32}$ also mentioned that a high concentration of ammonia $\left(\mathrm{NH}_{4}{ }^{+}\right.$, $690 \mathrm{mg} \mathrm{L}^{-1}$ ) shows no significant inhibition of the anammox process during the process of ammonia plant wastewater 
treatment. However, with deep research into anammox and partial denitrification coupling, ${ }^{33-35}$ it was found that the above situation is likely caused by the fact that the content of FA (free ammonia, $\mathrm{NH}_{3}$ ) in the sewage is less than the requirement of the inhibition value; therefore, the inhibitory effect on the anammox process is FA instead of $\mathrm{NH}_{4}{ }^{+}$.

Compared with $\mathrm{NH}_{4}{ }^{+}$, FA can diffuse more easily into biological cells through the lipid membrane. In the mechanism of FA inhibition, the FA changes the $\mathrm{pH}$ (as eqn (4)) of the intracellular environment after it enters the cells ${ }^{\mathbf{6}, 35}$ (intracellular $\mathrm{pH}$ $<$ extracellular $\mathrm{pH}$ ). High or low $\mathrm{pH}$ destroys the transmembrane potential and changes the substance exchange selectivity between the cells and the external environment; this will interfere with the synthesis of enzymes, leading to cell inactivation or even death.

$$
C_{\mathrm{FA}}=\frac{17}{4} \frac{C_{t, \mathrm{NH}_{3}} \times 10^{\mathrm{pH}}}{\left[\exp (6334 /(273+T))+10^{\mathrm{pH}}\right]}
$$

Fernández et $a l^{36}$ analyzed the short-term and long-term effects of FA on the anammox process. As a result, with shortterm exposure, as the concentration of FA increased from 38 to $100 \mathrm{mg} \mathrm{L}^{-1}$, the metabolic activity was inhibited by $50 \%$ to $80 \%$; these inhibition concentrations (ICs) were recorded as the $\mathrm{IC}_{50}$ and $\mathrm{IC}_{80}$, respectively. However, in their study of long-term effects, anammox showed decreased nitrogen removal performance when the FA concentration was only 35 to $40 \mathrm{mg} \mathrm{L}^{-1}$. Summarized from many related research studies (Table 2), the activity threshold (initiation inhibition concentration) of FA on anammox is 20 to $25 \mathrm{mg} \mathrm{L}^{-1}$, and $\mathrm{FA}<5 \mathrm{mg} \mathrm{L}^{-1}$ can afford higher nitrogen removal efficiency.

The inhibition concentration of FA for denitrifying bacteria was only $7.5 \mathrm{mg} \mathrm{L}^{-1}$ as reported by Vadivelu et al. ${ }^{37}$ However, Nair et $a .^{151}$ and Waki et $a .^{38}$ both noted that a certain concentration of FA can enhance the activity of microorganisms, especially in the denitrification process. Higher concentrations of FA (exceeding the activity threshold) will inhibit biological activity, and long-term loading of denitrifying bacteria and anammox strains will cause large-scale deaths. It can be concluded that FA mainly affects biological activity (inhibition of reversibility) by affecting the biome structure. ${ }^{39,40}$ FA inhibition can be reduced by changing sewage operating conditions, such as $\mathrm{pH}, \mathrm{HRT}$, sludge type and sludge status (particles, biofilm or flocculation). He et al. ${ }^{41}$ stated that the safe concentration of FA in the reactor increased to $15 \mathrm{mg} \mathrm{L}^{-1}\left(\mathrm{IC}_{10}\right)$ after $\mathrm{pH}$ elevation. Compared with a granular sludge reactor, Yang et al. $^{42}$ added a composite support to the anammox reactor to increase reactor stability and FA tolerance and proved that nitrogen removal performance could be properly restored by reducing the $\mathrm{NH}_{4}{ }^{+}$concentration and increasing the hydraulic retention time (HRT). In addition, it is possible to domesticate bacteria under high concentrations of FA by applying restrictive conditions to the bacteria and obtain highly active anammox bacteria.

3.1.2 Free nitrous acid inhibition. In the coupling process of anammox and partial denitrification, both anammox and denitrifying bacteria were inhibited under a certain concentration of $\mathrm{NO}_{2}{ }^{-}$, and the inhibition of anammox was more obvious. ${ }^{11}$ Numerous studies ${ }^{4-52}$ have shown that $\mathrm{NO}_{2}{ }^{-}$inhibition is actually derived from the toxic effects of free nitrous acid (FNA), and the FNA concentration is affected by temperature, $\mathrm{pH}$ and $\mathrm{NO}_{2}{ }^{-}$concentration (eqn (5)). ${ }^{53}$ The FNA inhibition rate is about 3 times that of FA; Zhang et al. ${ }^{54}$ proved that FNA is the largest inhibitor of the coupling process, and the long-term stable operating concentration of the reactor should be controlled to less than $1.5 \mu \mathrm{g} \mathrm{L}^{-1}$.

$$
C_{\mathrm{FNA}}=\frac{47}{14} \frac{C_{t, \mathrm{NO}_{2}}}{\left[\exp (-2300 /(273+T)) \times 10^{\mathrm{pH}}\right]+1}
$$

In the mechanism of FNA inhibition, $\mathrm{NO}_{2}{ }^{-}$acts as a decoupling agent to diffuse into the membrane of prokaryotic cells; the permeability expansion of the cell membrane affects the enzymes involved in electron transport and proton transfer, thereby affecting the inhibition of the synthesis of adenosine triphosphate (ATP). ${ }^{55,56}$ Finally, it will affect the ATPasecatalyzed reaction and reduce biological activity. Studies have shown that in order to ensure safe and stable operation of the reactor, the $\mathrm{IC}_{10}$ value can usually be used as a safe value, ${ }^{54,57,58}$ and the FNA concentration should be controlled between 1.5 and $5 \mu \mathrm{g} \mathrm{L}^{-1}$. In this research, the coupling nitrogen removal efficiency could be improved with proper heating $\left(>25{ }^{\circ} \mathrm{C}\right)$ and low $\mathrm{pH}(<5.6)$, which could reduce the effects of the FNA concentration to ensure high activity of the strains. ${ }^{59}$

FNA inhibits the reduction of $\mathrm{N}_{2} \mathrm{O}$ to cause partial denitrification and accumulate $\mathrm{NO}_{2}{ }^{-}$. According to the research by Alinsafi et al. ${ }^{60}$ the amount of $\mathrm{N}_{2} \mathrm{O}$ released during wastewater treatment is positively correlated with the concentration of

\begin{tabular}{|c|c|c|c|c|c|c|c|c|}
\hline Reactor & $T /{ }^{\circ} \mathrm{C}$ & $\mathrm{pH}$ & $\mathrm{HRT} / \mathrm{d}$ & Sludge source & $\mathrm{NH}_{4}^{+} /\left(\mathrm{mg} \mathrm{L}^{-1}\right)$ & Time/d & Threshold & Reference \\
\hline UASB & $33-35$ & - & $0.375-0.5$ & Nitrification/denitrification $1: 1$ & $50-400$ & 187 & $29.65 \mathrm{mg} \mathrm{L}^{-1}$ & 42 \\
\hline SBR & 29 & - & $1.35-2.57$ & ELAN granular sludge & $500-1000$ & 175 & $23.55 \mathrm{mg} \mathrm{L}^{-1}$ & 43 \\
\hline MBR & $25 \pm 1$ & 8.0 & 0.5 & Anammox reactor & 100 & 800 & $16-23 \mathrm{mg} \mathrm{L}^{-1}$ & 44 \\
\hline MBBR & $34 \pm 0.8$ & - & 2 & Laboratory MBBR & $700 \pm 100$ & 275 & $25.5 \mathrm{mg} \mathrm{L}^{-1}$ & 45 \\
\hline SBR & $32-35$ & 7.9 & 0.5 & EGSB reactor & $429-513$ & 220 & $40 \mathrm{mg} \mathrm{L}^{-1}$ & 46 \\
\hline SBR & $33 / 30$ & 7.8 & - & SBR reactor & $70-2800$ & 200 & $35-40 \mathrm{mg} \mathrm{L}^{-1}$ & 36 \\
\hline SBR & $30-35$ & 7.8 & - & UASB reactor & $1615 \pm 68.5$ & 131 & $77 \mathrm{mg} \mathrm{L}^{-1}$ & 47 \\
\hline EGSB & 32 & 7.7 & - & - & $84-420$ & 70 & $>50 \mathrm{mg} \mathrm{L}^{-1}$ & 48 \\
\hline
\end{tabular}

Table 2 Research on the inhibitory threshold concentration of FA for anammox and denitrifying bacteria 
$\mathrm{NO}_{2}{ }^{-}$, which indirectly proves that an increase in FNA concentration can promote $\mathrm{N}_{2} \mathrm{O}$ reduction. Among the studies of FNA inhibition on denitrifying poly-phosphate accumulating organisms, Zhou et al. ${ }^{61}$ considered FNA as the main reason for the effects on $\mathrm{N}_{2} \mathrm{O}$ produced by the denitrification process, and they found that its inhibitory concentration was 0.7 to $1.0 \mu \mathrm{g}$ $\mathrm{L}^{-1}$. A low concentration of FNA provides mild coupling conditions for denitrification and anammox.

Niu et $a{ }^{62}$ proposed that the $\mathrm{IC}_{50}$ of FNA for anammox inhibition was in the range of $1.08-2.81 \mu \mathrm{g} \mathrm{L} \mathrm{L}^{-1}$, and it showed a higher nitrogen removal rate under FNA $<2 \mu \mathrm{g} \mathrm{L}^{-1}$. The inhibition of FNA can be reduced by changing the spatial structure (filler or carrier) of the biome, sludge state and operating conditions. Yang et al. $^{42}$ used shale ceramic particles and suspended spheres as carrier-loaded functional bacteria; their research showed that the initial value of FNA inhibition was as low as $77.02 \mu \mathrm{g} \mathrm{L}^{-1}$ and the anti-toxic performance was much lower than the anammox granular sludge $\operatorname{IC}_{50}\left(117 \mu \mathrm{g} \mathrm{L}^{-1}\right)$, which matched the research results of Puyol et al. ${ }^{52} \mathrm{He}$ et al. ${ }^{55}$ observed that the inhibition concentrations of anammox and some denitrifying bacteria communities ranged from 1.5 to 213 $\mu \mathrm{g} \mathrm{L}{ }^{-1}$ (Table 3).

\subsection{Organic inhibition}

Organic matter is of great significance to anaerobic and denitrifying bacteria. It acts as a carbon source for the denitrification process and as an inhibitor of the anammox process. There are numerous organic substances in sewage; these can be roughly classified into concentration inhibition type and toxicity inhibition type according to their inhibition mechanisms. Studies on the concentration and inhibition mechanisms of organics on the coupling process will help researchers to adjust the operating conditions of denitrification processes and improve their efficiency.

3.2.1 Concentration inhibition. There are two separate explanations for the mechanism of concentration-inhibiting organic inhibition. The first one is the inhibition of space competition. Within the inhibition of space competition, the organic matter is used by denitrifying bacteria as the carbon source, causing the proliferation rate of denitrifying bacteria to become much higher than that of anammox bacteria. Because the anammox bacteria have reduced living space, the number of bacteria and the nitrogen removal efficiency of anammox experience great reductions. ${ }^{67-69}$ The second explanation is the inhibition of metabolic pathway diversity. Scholars consider anammox to be the dominant strain in the system under a high concentration of organic matter; however, the metabolic mode can change. In the process, anammox bacteria uses organic matter as a substrate instead of $\mathrm{NO}_{2}{ }^{-}$and $\mathrm{NH}_{4}{ }^{+}$, which reflects the diversity of anammox metabolism. ${ }^{6,67,70}$ The two processes of anammox and organic oxidation are independent, and the anammox process can be re-expressed under inorganicdominated conditions. ${ }^{67}$

As shown in many studies, high concentrations of organic matter can inhibit the coupling nitrogen removal process, while lower concentrations can promote the growth and coupling of biomes. ${ }^{67,70,71}$ However, because the lack of a carbon source will inhibit the growth of denitrifying bacteria, the proper concentration of organic matter is vital to the anammox and coupling denitrification process; the effects of concentration on the anammox and denitrifying bacteria are shown in Table 4. Du et $a{ }^{13}{ }^{13}$ calculated the contribution rates of several nitrogen removal processes. It was found that the anammox nitrogen removal contribution rate was $78.9 \%$, and the domination of the anammox process was the real reason for the coupling and stable operation. When treating high-concentration organic wastewater (landfill leachate, mustard wastewater, etc.), it is possible to conclude that the appropriate addition of non-toxic organic substances (such as acetate, glucose and skim milk powder) can improve the activity of anammox and denitrifying bacteria and improve their coupling effects. ${ }^{16,72,73}$ The largest contribution rate of anammox during treatment of landfill leachate was only $23.4 \%$, recorded by Wei et al. ${ }^{28}$ The main reason is that functional COD in sewage is beneficial to the growth of denitrifying bacteria and inhibits the development of the anammox community. Continuing to inoculate sludge and optimize the influent parameters can promote the growth and reproduction of anammox bacteria and shorten the reactor startup time. Feng et al. ${ }^{74}$ studied the metabolism of anammox bacteria and found that under the condition of higher organic concentration, more energy consumption was required to produce EPS and amino acids accumulated in the cells, which reduced the contribution rate of anammox to nitrogen removal.

3.2.2 Toxicity inhibition. Inhibition of toxic organics occurs due to irreversible poisoning of microorganisms or inactivation of key enzymes. Several common toxic organics are alcohols, aldehydes, phenols and antibiotics.

Table 3 Research on the effects of FNA on anammox and denitrifying bacteria

\begin{tabular}{|c|c|c|c|c|c|c|c|c|c|}
\hline Reactor & $T /{ }^{\circ} \mathrm{C}$ & $\mathrm{pH}$ & $\mathrm{HRT} / \mathrm{h}$ & $\mathrm{NO}_{2}{ }^{-}-\mathrm{N} \mathrm{mg} \mathrm{\textrm {L } ^ { - 1 }}$ & $\mathrm{FNA} / \mu \mathrm{g} \mathrm{\textrm {L } ^ { - 1 }}$ & Sludge & Effect & Time/d & Reference \\
\hline UASB & $35 \pm 1$ & $7.5-7.8$ & $12-1.5$ & $130-260$ & $0.67 / 2.81$ & Granule sludge & $\mathrm{IC}_{10} / \mathrm{IC}_{50}$ & 900 & 62 \\
\hline EGSB & $35 \pm 1$ & $7.1-7.3$ & $1.5-3$ & $117.8-710$ & 15 & Digested sludge & $\mathrm{IC}_{10}$ & 400 & 41 \\
\hline UASB & $35 \pm 1$ & $7.5-7.9$ & $1.5-3$ & 229.7 & 17 & Granule sludge & $\mathrm{IC}_{10}$ & 700 & 63 \\
\hline AAFEB & 35 & $7.5-8.5$ & 3 & 533.8 & $12-19$ & Biofilm/granule & $\mathrm{IC}_{10}$ & 300 & 64 \\
\hline CSTAn & $25 \pm 3$ & $7.0-7.3$ & $12-24$ & $300-400$ & $70 \pm 10$ & Digested sludge & Restrain & 180 & 65 \\
\hline EGSB & $30 \pm 2$ & $6.5-7.3$ & - & 160 & 19 & Granule sludge & $\mathrm{IC}_{10}$ & - & 52 \\
\hline UASB & $35 \pm 1$ & $7.5-8.2$ & 4 & $210-420$ & 6 & Anammox & No & 600 & 66 \\
\hline SBR1/2 & $30 / 33$ & 7.8 & 24 & $70-420$ & 11 & Biofilm & $\mathrm{IC}_{50}$ & 200 & 36 \\
\hline
\end{tabular}


Table 4 Research on the inhibitory effects of the organic matter concentration on anammox and denitrifying bacteria

\begin{tabular}{|c|c|c|c|c|c|c|c|c|c|}
\hline Reactor & $T /{ }^{\circ} \mathrm{C}$ & $\mathrm{pH}$ & $\mathrm{HRT} / \mathrm{d}$ & Sludge & Carbon source & $c\left(\mathrm{mg} \mathrm{L^{-1 }}\right)$ & Effect & Time/d & Reference \\
\hline MBfR & $22 \pm 2$ & $7.0-8.0$ & 1.1 & Biofilm & Methane & $0.24-1.21 \mathrm{~atm}$ & Increased activity & 70 & 75 \\
\hline UASB & 35 & $7.8-8$ & 1.5 & Granule sludge & Skim milk powder & $0-400$ & $\mathrm{C} / \mathrm{N}$ threshold value 3.1 & 30 & 76 \\
\hline- & 20 & 7.4 & 2.6 & Activated sludge & Pig wastewater & $2200 / 6.4$ & No & 25 & 38 \\
\hline USB & $28-35$ & $7-8$ & - & Mixed sludge & Landfill leachate & $1400-2000$ & Restraint & 90 & 14 \\
\hline UASB & $25-32$ & 7.9 & 0.67 & Activated sludge & Livestock wastewater & $254 \pm 115$ & No & 190 & 68 \\
\hline EGSB & $35 \pm 1$ & - & - & Anammox sludge & Glucose & $\mathrm{C} / \mathrm{N}: 1.6$ & Increased activity & 91 & 77 \\
\hline- & $30 \pm 1$ & 7.2 & $1-2$ & Granule sludge & Sodium acetate & $0-40$ & Increased activity & 400 & 73 \\
\hline SBR & 35 & 7.5 & - & Biofilm & Methane & Enough & Restraint & 200 & 78 \\
\hline
\end{tabular}

Table 5 Inhibition of anammox and denitrification by antibiotics

\begin{tabular}{|c|c|c|c|c|c|c|}
\hline Type & Antibiotic & $T /{ }^{\circ} \mathrm{C}$ & $\mathrm{pH}$ & $c\left(\mathrm{mg} \mathrm{L}^{-1}\right)$ & Effect & Reference \\
\hline$\beta$-Lactam & Penicillin G-Na & $20 \pm 1$ & $7.0 \pm 0.05$ & 4946.4-5282.4 & $-50 \%$ & 82 \\
\hline G-Antibiotic & Polymyxin B sulfate & & & $1.8-18.6$ & $-50 \%$ & \\
\hline Amide alcohol & Chloramphenicol & & & $333.7-486.1$ & $-50 \%$ & \\
\hline Aminoglycosides & Kanamycin sulfate & & & $3934.4-6573.8$ & $-50 \%$ & \\
\hline Macrolides & Erythromycin & $25 \pm 1$ & $7.8 \pm 0.1$ & 20 & $-50.6 \%$ & 83 \\
\hline Quinolones & Norfloxacin & $24 \pm 1.9$ & $8.2 \pm 0.07$ & 0.001 & $-39.6 \%$ & 84 \\
\hline Macrolides & Erythromycin & $24 \pm 1.3$ & $8.1 \pm 0.04$ & 0.001 & A few & \\
\hline Tetracycline & Oxytetracycline & $35 \pm 1$ & $8.4 \pm 0.11$ & 2 & $-81.3 \%$ & 85 \\
\hline
\end{tabular}

(1) Alcohols, aldehydes and phenols. The main toxic alcohols are methanol and ethanol. The inhibition mechanisms are that methanol will be converted to aldehydes by methanol dehydrogenase, and ethanol will be converted to acetyl coenzyme before being oxidized to acetaldehyde. ${ }^{79}$ As noted in previous research, there was no accumulation of $\mathrm{NO}_{2}{ }^{-}$in a reactor with added methanol; the contribution rate of anammox denitrification continuously decreased, and the coupling system was seriously inhibited. Peng et al. ${ }^{80}$ analyzed the methanol in the reactor experimentally; they found that anammox had no activity at 3 to $4 \mathrm{mmol}$ methanol, and the inhibition was irreversible.

Phenols originate from manufacturing wastewater (such as paper, textile and pharmaceutical); also, there are small amounts of phenols in urban sewage. Lyu et al. ${ }^{81}$ stated that when the phenol concentration was set at $400 \mathrm{mg} \mathrm{L}^{-1}$ and $1000 \mathrm{mg} \mathrm{L^{-1 }}$ in intermittent experiments, the anammox removal rate decreased by $56 \%$ and $76 \%$, respectively. Through inhibiting the activity of anammox strains and changing the microbial community structure, the experiment reduced the nitrogen removal rate. Studies by Peng et al..$^{80}$ pointed out that the inhibitory strength of benzenes is related to their substituent groups, and the relationships between them are as follows: $-\mathrm{COOH}<-\mathrm{SO}_{3}-\mathrm{H}<-\mathrm{H}<-\mathrm{OH}<-\mathrm{CH}_{3}<-\mathrm{CHO}<-\mathrm{OCH}_{3}<-\mathrm{Cl}$. When benzene, toluene, phenol and benzoic acid are taken as carbon sources, their $\mathrm{IC}_{50} \mathrm{~s}$ are about 9.21 (7.80 to 10.62), 35.28 (30.16 to 40.40), 124.55 (113.51 to 135.59) and 3833.12 (3481.57 to 4184.67$) \mathrm{mg} \mathrm{L}^{-1}$, respectively.

(2) Antibiotics. Antibiotics are biopharmaceuticals and are found in wastewater, such as aquaculture wastewater, livestock

Table 6 Research on the effects of salinity on anammox and denitrifying bacteria

\begin{tabular}{|c|c|c|c|c|c|c|}
\hline Reactor & $\mathrm{HRT} / \mathrm{d}$ & Salt type & $c\left(\mathrm{~g} \mathrm{~L}^{-1}\right)$ & Effect & Time/d & References \\
\hline SBR & $1.4-2.6$ & $\mathrm{NaCl}$ & $1.75-18.33$ & $\begin{array}{l}\text { Anammox activity }-94 \% \text {, nitrogen } \\
\text { removal rate }-70 \%\end{array}$ & 215 & 43 \\
\hline SBR & - & Seawater & $3.5-35$ & $\begin{array}{l}\text { Short-term } 30 \mathrm{~g} \mathrm{~L}^{-1} \text { activity }-30 \% \text {, long- } \\
\text { term } 35 \mathrm{~g} \mathrm{~L}^{-1} \text { activity }-42 \%\end{array}$ & 3 year & 90 \\
\hline SBBGRs & 2 & $\mathrm{NaCl}$ & $0-5 \%$ & Activity $-40 \%$ & 241 & 91 \\
\hline Batch & - & $\mathrm{NaCl}$ & $25-125$ & $\begin{array}{l}100 \mathrm{~g} \mathrm{~L}^{-1} \mathrm{AOB}, \text { no effect, } 125 \mathrm{~g} \mathrm{~L}^{-1} \text { start } \\
\text { suppression }\end{array}$ & - & 93 \\
\hline EGSB & - & $\mathrm{NaCl}$ & $5-12$ & Increased heat resistance & 2 year & 94 \\
\hline- & $0.25-0.5$ & $\mathrm{NaCl}$ & $0 / 3 / 25 / 45$ & Inhibition $0 / 23.43 / 48.89 / 67.94$ & 120 & 95 \\
\hline
\end{tabular}




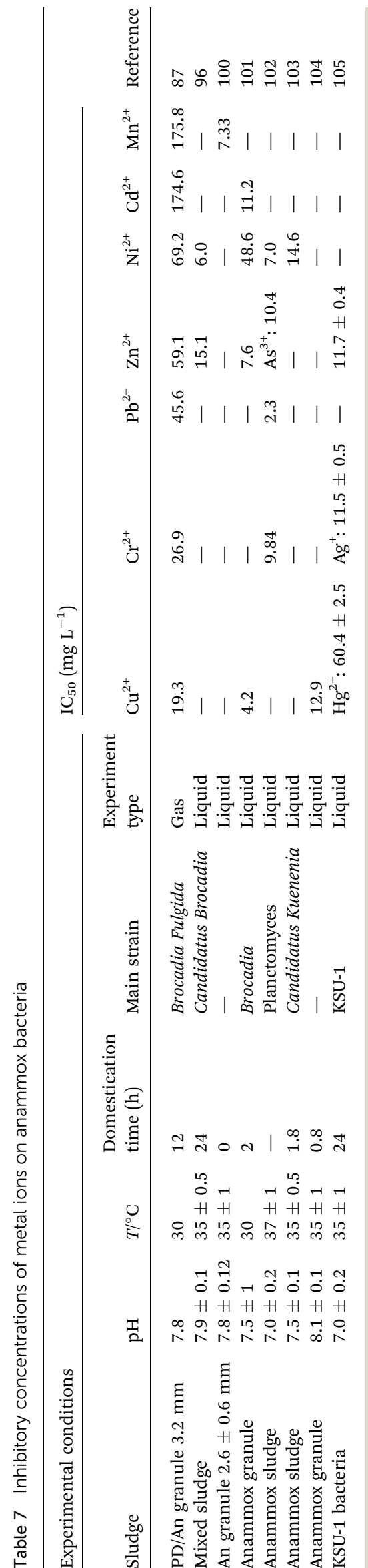

wastewater and surface water. Because of their antibiotic actions, microorganisms are inhibited or killed, and antibiotics have obvious inhibitory effects on anammox and denitrifying bacteria in sewage treatment (Table 5). Ding et al. ${ }^{82}$ studied the effects of different antibiotics on anammox and found that the order of toxicity of various antibiotics was as follows: polymyxin $\mathrm{B}>$ chloramphenicol $>$ penicillin G-Na $>$ kanamycin sulfate. The $\mathrm{IC}_{50}$ inhibition concentrations of these antibiotics were 5114.4 (4946.4 to 5282.4), 10.2 (1.8 to 18.6), 409.9 (333.7 to 486.1) and 5254.1 (3934.4 to 6573.8 ) $\mathrm{mg} \mathrm{L}^{-1}$, respectively; moreover, the simultaneous toxicity of multi-component antibiotics shows synergism. According to the research by Zhang et $a{ }^{83}$ on the effects of erythromycin on the coupling process, transient inhibition occurred at low concentration (expressed as low-dose addition inhibition), but the activity could be restored in a short time; however, the inhibitory effect was irreversible when a higher concentration was added.

\subsection{Salt inhibition}

Salt will affect the infiltration of the inside and outside environments of microbial cells. This process creates an osmotic pressure difference that will cause cell death or cleft of microorganisms. This phenomenon exists in some wastewater, such as seafood processing wastewater, mustard production wastewater, dyeing wastewater, and petroleum production wastewater. ${ }^{86}$ Salt-tolerant microorganisms can be obtained by high salinity acclimation or directly from the ocean.

For example, Giustinianovich et al. ${ }^{43}$ found that the activity of anammox was inversely proportional to the salt concentration in the treatment of canned fish wastewater. When the concentration of $\mathrm{NaCl}$ increased from 1.75 to $18 \mathrm{~g} \mathrm{~L}^{-1}$, the activity of anammox decreased by $94 \%$, while the coupling nitrogen removal rate of anaerobic ammonia nitrogen was reduced to $30 \%$. However, direct exposure of anammox to $18 \mathrm{~g}$ $\mathrm{L}^{-1} \mathrm{NaCl}$ for acclimation resulted in higher activity of anammox bacteria and a higher denitrification rate. In another study, the microbial community was subjected to short-term high load salinity (3.4 to $12.2 \mathrm{~g} \mathrm{~L}^{-1}$ ), ${ }^{87}$ and it was found that anammox and denitrifying bacteria were inhibited when the salt was added; however, they could restore their activity within a short time and maintained stable operation in wastewater. Additionally, the influences of the concentration values of different salts are dissimilar; Dapena et al. ${ }^{88}$ stated that the $\mathrm{IC}_{50} \mathrm{~S}$ of $\mathrm{Na}_{2} \mathrm{SO}_{4}, \mathrm{NaCl}$, and $\mathrm{KCl}$ were 11.36, 13.46, and $14.9 \mathrm{~g} \mathrm{~L}^{-1}$, respectively (Table 6).

\subsection{Other inhibition}

3.4.1 Metal inhibition. Metals can inhibit microbial metabolism in wastewater treatment processes, especially heavy metals. They affect the microbial activity, cell structure, biological species and population structure by changing cell membrane permeability, synthesizing specific expressed proteins and small organic acids, and forming poorly soluble inorganic substances. Research on heavy metals has achieved abundant outcomes (Table 7); most metals have inhibitory effects on microorganisms. Val del Río et al. ${ }^{87}$ studied the $\mathrm{IC}_{50}$ values of $\mathrm{Cu}^{2+}, \mathrm{Cr}^{2+}, \mathrm{Pb}^{2+}, \mathrm{Zn}^{2+}, \mathrm{Ni}^{2+}, \mathrm{Cd}^{2+}$ and $\mathrm{Mn}^{2+}$ on 
$\wedge$

ป

anammox bacteria, and the respective results were as follows:

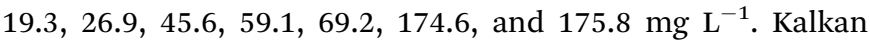
et al. ${ }^{96}$ also focused on the short-term impact of anammox $\mathrm{IC}_{50}$. However, Chen et al. ${ }^{97}$ added some metal ions to the reactor, namely $\mathrm{Fe}^{3+}\left(6.61 \mathrm{mg} \mathrm{L}{ }^{-1}\right), \mathrm{Cu}^{2+}\left(1.18 \mathrm{mg} \mathrm{L}{ }^{-1}\right)$, and $\mathrm{Ni}^{2+}$ $\left(1.11 \mathrm{mg} \mathrm{L}^{-1}\right)$; it was found that the anammox nitrogen removal rate increased by $50 \%$, and this phenomenon showed that metal ions may have positive influences on anammox bacteria. ${ }^{98}$ Studies have found that low concentrations of $\mathrm{Cu}^{2+}(0.05$ to $0.56 \mathrm{mg} \mathrm{L}^{-1}$ ) will inhibit the activity of denitrifying bacteria, while $\mathrm{Zn}^{2+}$ will promote the growth and reproduction of denitrifying bacteria at lower concentrations. ${ }^{66}$ Moreover, higher concentrations $\left(>30 \mathrm{mg} \mathrm{\textrm {L } ^ { - 1 }}\right.$ ) will produce inhibition, ${ }^{99}$ and when two kinds of metal ions impact denitrifying bacteria, the superimposed effect on denitrifying bacteria is slightly weaker.

3.4.2 Sulfide and phosphate inhibition. Sulfides and phosphides are common stepless inhibitors of the anammox and denitrification process. In the coupling denitrification process, $\mathrm{SO}_{4}{ }^{2-}$ and $\mathrm{NO}_{2}{ }^{-}$are simultaneously reduced by anammox bacteria, which function as electron acceptors to produce $\mathrm{H}_{2} \mathrm{~S}$ and $\mathrm{N}_{2}$. The produced sulfide $\left(\mathrm{H}_{2} \mathrm{~S}\right)$ will inhibit the anammox process and may be the dominant species (sludge inoculation). There are differences between the operating conditions and the inhibition effects in each study ${ }^{\mathbf{8 8 , 1 0 6 , 1 0 7}}$ Zhang et $a .^{108}$ studied the effects of phosphate on different morphologies of sludge (anammox particles and flocs) through batch experiments and found that phosphate can reduce the abundance of bacteria in the sludge but has less effect on the dominant strain (Candidatus Kuenenia stuttgartiensis). Moreover, according to the study, the $\mathrm{IC}_{50}$ values of the phosphate medium for anammox particles and flocs were 1664.7 \pm 114.7 and $1205.9 \pm 7.5 \mathrm{mg} \mathrm{L}^{-1}$, respectively. In studies of the effects of sulfides and phosphates on anammox and denitrification, the bacterial strains used are relatively few, and other bacteria should be studied in the future.

\section{Operational regulation of the coupling process}

In order to operate the coupling process efficiently and economically, the coupling parameters should be adjusted to increase the denitrification rate and reduce the inhibition effect. The adjusting methods include: (1) Mechanical treatment (sedimentation or filtration). (2) Operating parameter control ( $\mathrm{pH}, \mathrm{DO}$ or $\mathrm{T}$ ). (3) Sludge control (sludge selection, domestication or residence time). (4) Modification of the reactor operation strategy.

\subsection{Parameter control}

4.1.1 $\mathrm{pH}$ and $\mathrm{T}$. $\mathrm{pH}$ is the main factor affecting the concentration of FA and FNA; it has independent effects on FA and FNA inhibition. Low pH will increase FNA concentration (eqn (5)), and high pH will increase FA concentration (eqn (4)). By adjusting to the appropriate $\mathrm{pH}, \mathrm{FA}$ and FNA inhibition can be reduced. According to eqn (1) and (3), the anammox and partial denitrification coupling nitrogen removal process will 
consume $\mathrm{H}^{+}$(alkali production process) and the $\mathrm{pH}$ will increase. ${ }^{109}$ In order to ensure better metabolic and propagation conditions and a higher nitrogen removal rate, the $\mathrm{pH}$ of the inlet water should be adjusted to neutral or weakly acidic. If the amount of alkali production is uncertain, slightly alkaline inlet water is more suitable. ${ }^{\mathbf{1 1 0 , 1 1 1}}$ It is suitable for slightly alkaline inlet water.

According to the study by Strous et al., ${ }^{9}$ the $\mathrm{pH}$ should be controlled within the range of 7.0 to 8.0 ; the optimal physiological $\mathrm{pH}$ range of anammox in a single system is 6.7 to 8.3, while the optimal growth $\mathrm{pH}$ of denitrifying bacteria is 6 to 9 and the optimal coupling $\mathrm{pH}$ is 8.0. Similar studies ${ }^{\mathbf{1 1 1}}$ have found that a suitable range for anammox bacteria growth is $\mathrm{pH}$ 7.0 to 8.5; denitrifying bacteria have little effect at $\mathrm{pH} 7.0$ to 8.0, while the optimal pH load for anammox and partial denitrification coupling is 7.0 to 8.0 . If the $\mathrm{pH}$ is lower $(<5.06)$ or higher $(>9.00)$, it will affect the concentration of substrates and inhibitors in the water environment, influencing the growth and reproduction of anammox and denitrifying bacteria. Thereby, the electrolyte balance in the cell is destroyed to achieve the purpose of inhibiting the bacteria. ${ }^{112}$ Puyol et al. ${ }^{52}$ confirmed that high pH is more serious than FA inhibition, and maintaining an appropriate $\mathrm{pH}$ value is crucial for the stability of the bacterial community structure. Strous et al. ${ }^{9}$ pointed out that adding $\mathrm{HCO}_{3}{ }^{-}$to water is an effective method to regulate $\mathrm{pH}$, and proper $\mathrm{pH}$ conditions will enrich the bacterial community and lead to a higher nitrogen removal rate.

The survival temperature of anammox bacteria is between $20{ }^{\circ} \mathrm{C}$ and $40{ }^{\circ} \mathrm{C}$, and the optimal temperature range for nitrogen removal is $30{ }^{\circ} \mathrm{C}$ to $40{ }^{\circ} \mathrm{C} .{ }^{111,113}$ Higher temperature $\left(>45{ }^{\circ} \mathrm{C}\right)$ will irreversibly inhibit the activity of anammox bacteria, and the life activity of bacteria at lower temperature $\left(<10{ }^{\circ} \mathrm{C}\right)$ is completely stopped..$^{111}$ The optimal growth temperature range of denitrifying bacteria is $20{ }^{\circ} \mathrm{C}$ to $35^{\circ} \mathrm{C}$; excessively high or low temperature will cause changes in the physical structures of cell membranes (lipids and proteins). ${ }^{113}$ Much research has shown that maintaining the temperature at $30{ }^{\circ} \mathrm{C}$ to $35{ }^{\circ} \mathrm{C}$ is optimum for anammox and partial denitrification coupling. ${ }^{45,55,114}$

Although the bacteria can be inactivated at high temperature, the demand and application of high temperature denitrification cannot be hindered. Zhang et al. ${ }^{\mathbf{9 4}}$ increased the salinity appropriately to improve the heat resistance of anaerobic microorganisms (anammox). The optimum temperature is extended to $40{ }^{\circ} \mathrm{C}$ to $50{ }^{\circ} \mathrm{C}$. In recent years, low and medium temperature coupling technology for denitrification has become a research focus point. Cheng et al. ${ }^{115}$ studied urban river sludge and found that the anammox rate is higher in winter than in summer, while the denitrification rate is higher in summer than in winter; this phenomenon provides an opportunity for the application of coupled nitrogen removal technology. The studies by Gilbert et al. ${ }^{116}$ showed that the temperature effect is closely related to the shape of the biomass. It was also found that the activities of the granular and carrier biofilm species (anammox) can be maintained at a temperature below $13{ }^{\circ} \mathrm{C}$; however, the activity of suspended species begins to be suppressed at temperatures below $15^{\circ} \mathrm{C}$. The comparison shows that the thicker the biofilm in the low temperature environment, the higher the environmental adaptability and the stronger the resistance to temperature impact. According to the studies by Lotti et al. ${ }^{117}$ the anammox and partial denitrification coupling process can work well at low and medium temperatures $\left(15{ }^{\circ} \mathrm{C}\right.$ to $\left.25^{\circ} \mathrm{C}\right)$. Anammox bacteria that are biologically active in high or low temperature environments (85 ${ }^{\circ} \mathrm{Cand}-2{ }^{\circ} \mathrm{C}$ ) are also found in nature, ${ }^{\mathbf{1 1 8 , 1 1 9}}$ which provides the possibility of denitrification in wastewater at different temperatures. However, the anammox and denitrifying bacteria that survive at higher or lower temperatures cannot meet the optimal temperature of enzyme activity. Further exploration of the optimal temperature requirement of enzyme activity coupling with anammox and denitrification is needed. In addition, the temperature affects the FA and FNA concentrations. As shown in eqn (4) and (5), temperature is an important parameter for stable operation control of the reactor.

4.1.2 DO and ORP. Dissolved oxygen (DO) is one of the key parameters for coupling control of anammox and partial denitrification. The living environment of DO for anammox bacteria is usually controlled at 0.6 to $0.8 \mathrm{mg} \mathrm{L}^{-1}$. Generally, lower DO $(<2 \%$ air saturation) will inhibit the life activity of anammox bacteria (reversible), while higher DO (>18 air saturation) will irreversibly inhibit the bacteria. ${ }^{\mathbf{1 2 0}}$ Anammox bacteria will die when exposed to an excessive DO environment, and the living environment of DO for denitrifying bacteria is close to zero; therefore, the coupling of anammox and some denitrification bacteria needs to occur in a low oxygen environment. ${ }^{58}$ Due to the mutual difference between oxidase and nitrite reductase, higher DO will inhibit nitrate reduction. ${ }^{\mathbf{1 0 6}}$ When anammox and partial denitrification are coupled, the DO should be controlled below $0.7 \mathrm{mg} \mathrm{L}^{-1}$ to facilitate the coupling.

Oxidation-reduction potential (ORP) is used to characterize the macroscopic redox properties exhibited by substances in aqueous solution, and the ORP values are related to $\mathrm{DO}, \mathrm{pH}$, and organic matter concentration. ${ }^{\mathbf{1 2 1 , 1 2 2}}$ It has been noted that when anammox is coupled with partial denitrification, an ORP between -50 and $+50 \mathrm{mV}$ is beneficial for denitrification. ${ }^{\mathbf{1 0 6}} \mathrm{ORP}$ is widely used for online monitoring and parameter control of anammox, nitrification, and denitrification processes. A crowd of studies have shown that compared with other parameters (DO or $\mathrm{pH}$ ), ORP is a more consistent process control parameter. ${ }^{123}$ The ORP provides reliable control operating parameters for the stable operation of the anammox and partial denitrification coupling process. ${ }^{124}$

4.1.3 $\mathrm{C} / \mathrm{N}$ and $\mathrm{NO}_{2}{ }^{-} / \mathbf{N H}_{4}{ }^{+} . \mathrm{C} / \mathrm{N}$ is the key to start an anammox and partial denitrification coupling reactor, and it is also an important control parameter to maintain stable reactor operation and efficient nitrogen removal. ${ }^{19,30,125}$ The presence of organic matter is generally believed to have adverse effects on the anammox process because the heterotrophic denitrifying bacteria grow at a much higher rate and with a higher cellular synthesis growth yield compared to autotrophic anammox bacteria. ${ }^{106}$

Anammox bacteria are autotrophic bacteria, and the participation of organic carbon will inhibit bacterial growth. Sheng et al. ${ }^{77}$ studied the effects of different organics and $\mathrm{C} / \mathrm{N}$ on the 
SAD process; although the biological community believed that in a low COD environment, the anammox bacteria were dominant $(\mathrm{C} / \mathrm{N}=0.8)$, they found that the denitrifying bacteria grew faster under a high carbon-nitrogen ratio $(\mathrm{C} / \mathrm{N}=1.2)$. Wang et $a{ }^{129}$ performed batch tests and indicated that anammox collaborates well with denitrification at low $\mathrm{C} / \mathrm{N}(\mathrm{C} / \mathrm{N}=1.0)$. Miao et al. ${ }^{\mathbf{1 2 6}}$ found that when the $\mathrm{C} / \mathrm{N}$ of the reactor inlet water was adjusted from 1.1 to 2.5 , the increase of $\mathrm{C} / \mathrm{N}$ promoted the growth of denitrifying bacteria and inhibited the growth rate of anammox bacteria (the abundance and activity of anammox bacteria remained stable). Influent $\mathrm{C} / \mathrm{N}$ directly affects the competition between autotrophic and heterotrophic microorganisms, and most denitrifying bacteria are heterotrophic microorganisms; therefore, a higher influent $\mathrm{C} / \mathrm{N}$ is beneficial to the growth of denitrifying bacteria. Miao et al. ${ }^{\mathbf{1 2 6}}$ reported that $\mathrm{C} / \mathrm{N}$ low-load wastewater was adjusted as the $\mathrm{C} / \mathrm{N}$ increased from 1.0 to 2.5; the contribution of denitrification to $\mathrm{TN}$ removal gradually increased, and denitrifying bacteria also accumulated. Cao et $a .^{12}$ reported that the contribution of denitrification to $\mathrm{TN}$ removal is directly proportional to $\mathrm{C} / \mathrm{N}$, confirming the effects of $\mathrm{C} / \mathrm{N}$ on denitrifying bacteria.

Studies have shown ${ }^{\mathbf{1 2 6}}$ that the $\mathrm{C} / \mathrm{N}$ the reactor can accept is related to the thickness of the biofilm. Thicker biofilms can maintain a good nitrogen removal rate even with high $\mathrm{C} / \mathrm{N}(\mathrm{C} /$ $\mathrm{N}=10)$. When the biofilm is thin and sensitive, low $\mathrm{C} / \mathrm{N}(\mathrm{C} / \mathrm{N}$ $=2$ ) can also inactivate microorganisms. $\mathrm{C} / \mathrm{N}$ has a significant effect on the accumulation of $\mathrm{NO}_{2}{ }^{-}-\mathrm{N}$. Therefore, in the treatment of sewage with less organic matter, an additional carbon source must be used to determine the $\mathrm{NO}_{3}{ }^{-}-\mathrm{N}$ content in the sewage. In the study of separated and combined partial denitrification and anammox coupling processes, a large number of literature reports have noted that the optimal range of $\mathrm{C} / \mathrm{N}$ adjustment for the startup and operation of the reactor is 2.0 to $3.0 .^{7,12,13,21,25}$

$\mathrm{NO}_{2}{ }^{-} / \mathrm{NH}_{4}{ }^{+}$is a direct parameter to measure the optimal removal rate of TN. Studies have shown that the optimal stoichiometric ratio $(1.32: 1$, often used as the nitrogen source addition ratio to start the coupling reactor) will reduce the TN removal rate. ${ }^{\mathbf{9} 127}$ When $\mathrm{NO}_{2}{ }^{-} / \mathrm{NH}_{4}{ }^{+}$is more than 1.3 during the nitrogen removal process, the $\mathrm{NO}_{2}{ }^{-}$in the reactor will gradually accumulate and affect the bacterial activity; when $\mathrm{NO}_{2}{ }^{-} / \mathrm{NH}_{4}{ }^{+}$is less than 1.3, despite the high denitrification rate, the anammox process is inhibited and the TN removal rate is reduced by $20 \%$ to $60 \% .^{128}$ Wang et al. ${ }^{129}$ stated that when $\mathrm{NO}_{2}{ }^{-} / \mathrm{NH}_{4}{ }^{+}$is between 0.1 and 0.5 , anammox and denitrifying bacteria can coexist; however, the denitrification contribution rate is significantly higher than that of anammox. The calculation of the nitrogen path shows that during the coupling process, ${ }^{13}$ anammox is the main denitrification method (accounting for $78.9 \%$ of the total denitrification amount), which is the real reason for the stable operation of the coupling process. Maintaining a suitable $\mathrm{NO}_{2}{ }^{-}$/ $\mathrm{NH}_{4}{ }^{+}$value with influent water (stoichiometry ratio $1.32: 1$ ) is an important parameter for the rapid start-up and stable operation of the coupling reactor.

4.1.4 Other parameters. The light effect is the inhibition by light of the activity of photosensitive microorganisms. ${ }^{9}$ Because anammox bacteria are light-sensitive microorganisms, light energy can inhibit the activity of anammox bacteria, reducing the nitrogen removal rate by $30 \%$ to $50 \%$. Therefore, protective measures should be taken in the laboratory environment to increase the nitrogen removal rate. ${ }^{26}$

Hydraulic residence time (HRT) is the average residence time of sewage to be treated in a reactor. In the process of anaerobic ammonia oxidation and partial denitrification coupling, proper increase of HRT can improve the TN removal rate. ${ }^{13}$ When the nitrogen removal process (or bacteria) is inhibited, adjusting to the appropriate HRT can effectively restore nitrogen removal performance (or bacterial activity). ${ }^{\mathbf{1 2 , 1 3 0 , 1 3 1}}$

\subsection{Sludge}

4.2.1 Sludge domestication. Anammox and partial denitrification coupling methods can be divided into split and integrated processes. In the split process, the sludge of absolute dominant bacteria (anammox and denitrification bacteria) is inoculated into two different reactors to remove nitrogen, which effectively avoids competition between the substrates and living space of microorganisms. ${ }^{132}$ The coupling process mainly starts by inoculating part of the denitrifying floc sludge and anammox granular sludge. $^{22,132,133}$ It has been reported that denitrifying sludge is obtained by acclimation of nitrifying sludge. ${ }^{122}$ The advantage of this process is that the anammox activity and denitrification activity are positively related, and the synergistic metabolism can greatly improve the $\mathrm{TN}$ removal rate. ${ }^{\mathbf{1 3 4 - 1 3 6}}$ Because the screening of the type of sludge is largely determined by the coupling process, the screening of functional anammox and denitrifying bacteria is often performed by adding screening factors (such as $\mathrm{pH}, \mathrm{T}$ and salt) to the sewage during process operation and commissioning. ${ }^{31}$ Because of the large difference in demand for sludge-dominant bacteria for sewage treatment performance goals, sludge must be domesticated and cultivated.

The most common sludge forms are biofilm, floc sludge (suspended state), and granular sludge. Raudkivi et al. ${ }^{137}$ stated that the tolerance performance of the three states during domestication is as follows: granular sludge $>$ biofilm $>$ flocculent sludge. Granular sludge and biofilm have high mass transfer resistance, which alleviates the inhibitory effects caused by transient impact and provides sufficient adaptation time for microorganisms. Therefore, in order to shorten the domestication time and achieve more bacteria load, it is important to choose appropriate sludge domestication.

4.2.2 Sludge retention. In order to maintain a stable anammox and partial denitrification coupling denitrification process, the sewage treatment system needs a sufficient sludge residence time (SRT). Jenni et al. ${ }^{\mathbf{1 3 8}}$ pointed out that when a sufficient SRT is ensured, anammox and denitrifying bacteria can coexist even at high $\mathrm{C} / \mathrm{N}$. Anammox and denitrifying bacteria can only be guaranteed when the SRT is longer than the doubling time of sludge. In order to obtain better denitrification performance, the typical doubling time of anammox is 15 to 30 days. ${ }^{139}$ It is necessary to ensure an appropriate SRT in the reactor, which is vital to achieve a high nitrogen removal rate in the coupling process. ${ }^{13,139}$ 


\subsection{Reactor quick start strategy}

The optimized reactor operating parameters will shorten the reactor startup time and also increase the speed of the actual industrial application process of anammox and partial denitrification coupling. Research on anammox and partial denitrification coupling technology is listed in Table 8. Methods of quick start strategy parameter control include sludge selection, adjustment of initial conditions and reactor commissioning.

4.3.1 Sludge selection. According to Zhou et al., ${ }^{140}$ adding quality sludge can shorten both the time of anammox and denitrification and the success time of the reactor. Moreover, when less active matrix anammox was added, the anammox and partial denitrification coupling reactor was successfully started and the start-up time was reduced by 5 days. Wang et al. ${ }^{141}$ inoculated anaerobic granular sludge (AGS) and activated sludge (AS) in a laboratory-scale reactor, and the reactor to which AS was added was successfully started; the reactor startup time shortened from 21 days to 5 days (TN removal rate was $70 \%$ ), while the reactor inoculated with AGS failed to start. Zhang et al. ${ }^{\mathbf{1 4 2}}$ added 5 different sludge EPS in the interval test of anammox activity; they noted that denitrifying sludge EPS (DSEPS) can increase the activity of anammox bacteria and shorten the startup time of the reactor.

4.3.2 Initial condition adjustment. When the reactor is started, the characteristics of the operating environment of the anammox and denitrifying bacteria (such as $\mathrm{T}, \mathrm{pH}$ or $\mathrm{NO}_{2}{ }^{-}$/ $\mathrm{NH}_{4}{ }^{+}$) are used as direct control variables for fast startup. Zhou et al. ${ }^{61}$ inoculated non-deoxygenated anammox and denitrifying sludge at room temperature from $24{ }^{\circ} \mathrm{C}$ to $30{ }^{\circ} \mathrm{C}$ and returned the washed-out sludge to the reactor to increase the residence time; this played an important role in the reactor startup and performance recovery. Yin et $a l .{ }^{\mathbf{1 4 3}}$ found that adding a small amount of reduced graphene oxide (RGO) to a started anammox reactor will increase the anammox bacteria activity, thereby shortening the reactor startup time and improving the nitrogen removal rate. Jara-Muñoz et al. ${ }^{\mathbf{1 4 4}}$ also quickly started the coupling reactor under two conditions of hypoxia and higher temperatures $\left(30{ }^{\circ} \mathrm{C}\right.$ to $\left.40{ }^{\circ} \mathrm{C}\right)$, with shortened the microbial doubling time. A number of studies have shown that during the coupling reactor start-up process, controlling the $\mathrm{NO}_{2}{ }^{-} / \mathrm{NH}_{4}{ }^{+}$ ratio at $1.32: 1$ is conducive to promoting the rapid growth of bacteria and shortening the reactor startup time.,.$^{\mathbf{9 1 0 6 , 1 4 5}}$

4.3.3 Reactor operation. During the operation of the reactor, it is necessary to regularly monitor the operating parameters (DO, $\mathrm{NO}_{2}{ }^{-}, \mathrm{NO}_{3}{ }^{-}$, etc.) to ensure better treatment performance (TN, COD removal rate, sludge concentration, etc.) and to debug the reactor operation parameters. These are conducive to the rapid startup and stable operation of the coupling reactor.

4.3.4 Improved reactor performance. Charles Glass et al. ${ }^{\mathbf{1 4 6}}$ observed that denitrification was inhibited at around $\mathrm{pH}$ 6.5, and the NAR increased significantly when the $\mathrm{pH}$ was adjusted from 7.5 to 9.0. It is worth noting that in the long-term and short-term effects of $\mathrm{pH}$ on denitrification, a high $\mathrm{pH}$ value is beneficial to achieve partial denitrification of nitrite accumulation. ${ }^{147-149}$ The SPDAF (synergizes the partial denitrification, anammox and in situ fermentation) collaborative process established by Ji et al. ${ }^{30}$ has the disadvantages of slow degradation of organic matter and low utilization rate. The sludge in the fermentation tank was inoculated into the UASB reactor to promote denitrification. The bacteria consumed a large amount of organic matter to produce more nitrite and increased the rate of nitrogen removal by anammox. Zhang et al. ${ }^{19}$ added sponge bio-carriers to facilitate the enrichment of microorganisms and the formation of EPS. The richness of the biofilms increased by 6 times and the TN removal rate was maintained at 93\%, which solved the problems of immature biofilms and insufficient anammox bacteria. Niu et al. ${ }^{27}$ investigated the stability of FA and FNA to the process and found that both FA and FNA affect the $\mathrm{TN}$ removal rate; therefore, the operating conditions were optimized to establish a clear parameter control range $(\mathrm{pH} 7.5$ to 8.5 , FA below $10 \mathrm{mg} / 100 \mathrm{mg} \mathrm{NH}_{4}{ }^{+}-\mathrm{N}$ and an FNA below 0.005 $\left.\mathrm{mg} / 100 \mathrm{mg} \mathrm{NO}{ }_{2}{ }^{-} \mathrm{N}\right)$, ensuring high nitrogen removal rate and effluent quality.

\section{Conclusion}

This paper discussed the coupling principles and inhibition mechanisms of anammox and summarized the coupling parameter control and optimization (or rapid) startup strategy. This paper focused on reviewing many practical issues that arise during the startup and nitrogen removal of anammox and some denitrification coupling reactors, summarizing the inhibition mechanisms and concentration control ranges of inhibition parameters (organics, salts, etc.), the influence and adjustment ranges of basic parameters ( $\mathrm{pH}, \mathrm{T}, \mathrm{DO}$, etc.), sludge differences (dominant bacteria), and reactor startup control strategies. Because anammox and partial denitrification coupling is affected by multiple parameters, it is utilized less in common sewage-treatment processes. In order to improve the denitrification performance and develop the coupling denitrification process, it is recommended that further studies on the coupling denitrification process focus on the following aspects:

(1) Research on the inhibition mechanisms. Studies on the inhibition performance and mechanisms of inhibitors, such as substrates, organic matter and salt.

(2) Optimization of operating parameters. Based on the anammox and partial denitrification coupling reactor, combined with the actual bio-dominant species (or characteristic strains), the optimal operating parameters should be adjusted to guide the rapid startup and stable nitrogen removal of the reactor.

(3) Research on the mass transfer mechanism. Based on the state of the sludge (particles, flocculent, etc.) and the distribution of strains in the sludge, studies can be conducted about the mass transfer mechanism under different conditions, the mass transfer relationship between the state of the sludge and the distribution of the species community.

(4) Recovery kinetics after inhibition. When the coupling is inhibited, some additives are often added to restore the activity of the partially coupling strains; therefore, the work process of the recovery process needs to be further explored. 
(5) Mathematical model for the coupling process. A unified mathematical model should be established for the coupling process of anammox and denitrification, which is helpful for grasping the mechanism of sewage treatment, predicting the state of sewage treatment, and optimizing the parameter of sewage treatment.

\section{Conflicts of interest}

There are no conflicts of interest to declare.

\section{Acknowledgements}

The authors gratefully acknowledge the financial support of the National Key Research and Development Program of China (2016YFE0205600), Chongqing Basic Research And Frontier Exploration Project of China (cstc2018jcyjAX0638), Innovation Group of New Technologies for Industrial Pollution Control of Chongqing Education Commission (CXQT19023), Opening Foundation in the Key Research Platforms (KFJJ2018069), Scientific Research Team Project (ZDPTTD201917) and Scientific Research Foundation (1952005) of Chongqing Technology and Business University, and the Program of Chongqing Municipal Education Commission (CY190801).

\section{References}

1 B. Kartal, J. G. Kuenen and V. M. C. M. Loosdrecht, Sewage treatment with anammox, Science, 2010, 328, 702.

2 M. M. Kuypers, H. K. Marchant and B. Kartal, The microbial nitrogen-cycling network, Nat. Rev. Microbiol., 2018, 16, 263.

3 R. Du, Y. Peng, S. Cao, B. Li, S. Wang and M. Niu, Mechanisms and microbial structure of partial denitrification with high nitrite accumulation, Appl Microbiol Biot, 2016, 100, 2011-2021.

4 D. Zhang, S. Xu, P. Antwi, L. Xiao, W. Luo, Z. Liu, J. Li, H. Su, C. Lai and F. Ayivi, Accelerated start-up, long-term performance and microbial community shifts within a novel upflow porous-plated anaerobic reactor treating nitrogen-rich wastewater via ANAMMOX process, $R S C$ Adv., 2019, 9, 26263-26275.

5 M. C. Van Teeseling, R. J. Mesman, E. Kuru, A. Espaillat, F. Cava, Y. V. Brun, M. S. Vannieuwenhze, B. Kartal and N. L. Van, Anammox Planctomycetes have a peptidoglycan cell wall, Nat. Commun., 2015, 6, 6878.

6 R.-C. Jin, G.-F. Yang, J.-J. Yu and P. Zheng, The inhibition of the Anammox process: A review, Chem. Eng. J., 2012, 197, 67-79.

7 S. Cao, R. Du, Y. Peng, B. Li and S. Wang, Novel two stage partial denitrification (PD)-Anammox process for tertiary nitrogen removal from low carbon/nitrogen (C/N) municipal sewage, Chem. Eng. J., 2019, 362, 107-115.

8 B. Ma, W. Qian, C. Yuan, Z. Yuan and Y. Peng, Achieving Mainstream Nitrogen Removal through Coupling Anammox with Denitratation, Environ. Sci. Technol., 2017, 51, 8405-8413.
9 M. Strous, J. Heijnen, J. G. Kuenen and M. Jetten, The sequencing batch reactor as a powerful tool for the study of slowly growing anaerobic ammonium-oxidizing microorganisms, Appl. Microbiol. Biotechnol., 1998, 50, 589-596.

10 T. Lotti, R. Kleerebezem, C. Lubello and M. C. van Loosdrecht, Physiological and kinetic characterization of a suspended cell anammox culture, Water Res., 2014, 60, 1-14.

11 S. Dasgupta, S. Wu and R. Goel, Coupling autotrophic denitrification with partial nitritation-anammox (PNA) for efficient total inorganic nitrogen removal, Bioresour. Technol., 2017, 243, 700-707.

12 R. Du, S. Cao, S. Wang, M. Niu and Y. Peng, Performance of partial denitrification (PD)-ANAMMOX process in simultaneously treating nitrate and low $\mathrm{C} / \mathrm{N}$ domestic wastewater at low temperature, Bioresour. Technol., 2016, 219, 420-429.

13 R. Du, S. Cao, Y. Peng, H. Zhang and S. Wang, Combined partial denitrification (PD)-anammox: a method for high nitrate wastewater treatment, Environ. Int., 2019, 126, 707-716.

14 L. Wu, Z. Li, C. Zhao, D. Liang and Y. Peng, A novel partialdenitrification strategy for post-anammox to effectively remove nitrogen from landfill leachate, Sci. Total Environ., 2018, 633, 745-751.

15 S. Cao, R. Du, M. Niu, B. Li, N. Ren and Y. Peng, Integrated anaerobic ammonium oxidization with partial denitrification process for advanced nitrogen removal from high-strength wastewater, Bioresour. Technol., 2016, 221, 37-46.

16 X. Wang, J. Zhao, D. Yu, G. Chen, S. Du, J. Zhen and M. Yuan, Stable nitrite accumulation and phosphorous removal from nitrate and municipal wastewaters in a combined process of endogenous partial denitrification and denitrifying phosphorus removal (EPDPR), Chem. Eng. J., 2019, 355, 560-571.

17 J. Ji, Y. Peng, W. Mai, J. He, B. Wang, X. Li and Q. Zhang, Achieving advanced nitrogen removal from low $\mathrm{C} / \mathrm{N}$ wastewater by combining endogenous partial denitrification with anammox in mainstream treatment, Bioresour. Technol., 2018, 270, 570-579.

18 R. Du, S. Cao, B. Li, M. Niu, S. Wang and Y. Peng, Performance and microbial community analysis of a novel DEAMOX based on partial-denitrification and anammox treating ammonia and nitrate wastewaters, Water Res., 2017, 108, 46-56.

19 H. Zhang, R. Du, S. Cao, S. Wang and Y. Peng, Mechanisms and characteristics of biofilm formation via novel DEAMOX system based on sequencing biofilm batch reactor, J. Biosci. Bioeng., 2019, 127, 206-212.

20 Z.-Z. Zhang, Y.-F. Cheng, B.-Q. Zhu, Y.-Y. Liu, Q. Zhang and R.-C. Jin, Achieving completely anaerobic ammonium removal over nitrite (CAARON) in one single UASB reactor: synchronous and asynchronous feeding regimes of organic carbon make a difference, Sci. Total Environ., 2019, 653, 342-350. 
21 Z. Wang, L. Zhang, F. Zhang, H. Jiang, S. Ren, W. Wang and Y. Peng, Enhanced nitrogen removal from nitrate-rich mature leachate via partial denitrification (PD)-anammox under real-time control, Bioresour. Technol., 2019, 289, 121615.

22 R. Du, S. Cao, B. Li, H. Zhang, X. Li, Q. Zhang and Y. Peng, Step-feeding organic carbon enhances high-strength nitrate and ammonia removal via DEAMOX process, Chem. Eng. J., 2019, 360, 501-510.

23 M. Zhang, S. Wang, B. Ji and Y. Liu, Towards mainstream deammonification of municipal wastewater: partial nitrification-anammox versus partial denitrificationanammox, Sci. Total Environ., 2019, 692, 393-401.

24 Y. Qin, Y. Cao, J. Ren, T. Wang and B. Han, Effect of glucose on nitrogen removal and microbial community in anammox-denitrification system, Bioresour. Technol., 2017, 244, 33-39.

25 R. Du, S. Cao, X. Li, J. Wang and Y. Peng, Efficient partialdenitrification/anammox (PD/A) process through gasmixing strategy: System evaluation and microbial analysis, Bioresour. Technol., 2020, 300, 122675.

26 J. Li, Y. Peng, L. Zhang, J. Liu, X. Wang, R. Gao, L. Pang and Y. Zhou, Quantify the contribution of anammox for enhanced nitrogen removal through metagenomic analysis and mass balance in an anoxic moving bed biofilm reactor, Water Res., 2019, 160, 178-187.

27 Q. Niu, S. He, Y. Zhang, H. Ma, Y. Liu and Y.-Y. Li, Process stability and the recovery control associated with inhibition factors in a UASB-anammox reactor with a long-term operation, Bioresour. Technol., 2016, 203, 132-141.

28 H. Wei, X. Wang, M. Hassan, H. Huang and B. Xie, Strategy of rapid start-up and the mechanism of de-nitrogen in landfill bioreactor, J. Environ. Manage., 2019, 240, 126-135.

29 C.-C. Wang, P.-H. Lee, M. Kumar, Y.-T. Huang, S. Sung and J.-G. Lin, Simultaneous partial nitrification, anaerobic ammonium oxidation and denitrification (SNAD) in a fullscale landfill-leachate treatment plant, J. Hazard. Mater., 2010, 175, 622-628.

30 J. Ji, Y. Peng, B. Wang, X. Li and Q. Zhang, A synergistic partial-denitrification, anammox and in situ fermentation (SPDAF) process for advanced nitrogen removal from domestic and nitrate-containing wastewater, Environ. Sci. Technol., 2020, 54, 3702-3713.

31 M. Strous, J. G. Kuenen and M. S. Jetten, Key physiology of anaerobic ammonium oxidation, Appl. Environ. Microbiol., 1999, 65, 3248-3250.

32 K. Isaka, Y. Kimura, M. Matsuura, T. Osaka and S. Tsuneda, First full-scale nitritation-anammox plant using gel entrapment technology for ammonia plant effluent, Biochem. Eng. J., 2017, 122, 115-122.

33 M. Hauck, F. A. Maalcke-Luesken, M. S. M. Jetten and M. A. J. Huijbregts, Removing nitrogen from wastewater with side stream anammox: What are the trade-offs between environmental impacts?, Resour., Conserv. Recycl., 2016, 107, 212-219.

34 S. Ding, P. Bao, B. Wang, Q. Zhang and Y. Peng, Long-term stable simultaneous partial nitrification, anammox and denitrification (SNAD) process treating real domestic sewage using suspended activated sludge, Chem. Eng. J., 2018, 339, 180-188.

35 Y. Liu, H. H. Ngo, W. Guo, L. Peng, D. Wang and B. Ni, The roles of free ammonia (FA) in biological wastewater treatment processes: A review, Environ. Int., 2019, 123, 1019.

36 I. Fernández, J. Dosta, C. Fajardo, J. L. Campos, A. Mosquera-Corral and R. Mendez, Short- and long-term effects of ammonium and nitrite on the Anammox process, J. Environ. Manage., 2012, 95, S170-S174.

37 V. M. Vadivelu, J. Keller and Z. Yuan, Effect of free ammonia and free nitrous acid concentration on the anabolic and catabolic processes of an enriched Nitrosomonas culture, Biotechnol. Bioeng., 2006, 95, 830-839.

38 M. Waki, T. Yasuda, Y. Fukumoto, K. Kuroda and K. Suzuki, Effect of electron donors on anammox coupling with nitrate reduction for removing nitrogen from nitrate and ammonium, Bioresour. Technol., 2013, 130, 592-598.

39 Q. Wang, H. Duan, W. Wei, B. J. Ni, A. Laloo and Z. Yuan, Achieving Stable Mainstream Nitrogen Removal via the Nitrite Pathway by Sludge Treatment Using Free Ammonia, Environ. Sci. Technol., 2017, 51, 9800-9807.

40 S. Park, J. Chung, B. E. Rittmann and W. Bae, Nitrite accumulation from simultaneous free-ammonia and freenitrous-acid inhibition and oxygen limitation in a continuous-flow biofilm reactor, Biotechnol. Bioeng., 2015, 112, 43-52.

41 S. He, Y. Zhang, Q. Niu, H. Ma and Y.-Y. Li, Operation stability and recovery performance in an Anammox EGSB reactor after pH shock, Ecol. Eng., 2016, 90, 50-56.

42 W. Yang, S. He, M. Han, B. Wang, Q. Niu, Y. Xu, Y. Chen and H. Wang, Nitrogen removal performance and microbial community structure in the start-up and substrate inhibition stages of an anammox reactor, J. Biosci. Bioeng., 2018, 126, 88-95.

43 E. A. Giustinianovich, J. L. Campos, M. D. Roeckel, A. J. Estrada, A. Mosquera-Corral and A. Val Del Rio, Influence of biomass acclimation on the performance of a partial nitritation-anammox reactor treating industrial saline effluents, Chemosphere, 2018, 194, 131-138.

44 S. Sun, Y. Song, X. J. Yang, H. Hu, S. Wu, W.-k. Qi and Y.-Y. Li, Strategies for improving nitrogen removal under high sludge loading rate in an anammox membrane bioreactor operated at $25{ }^{\circ} \mathrm{C}$, Chem. Eng. Sci., 2018, 183, 106-114.

45 M. S. Kowalski, T. Devlin, A. di Biase, S. Basu and J. A. Oleszkiewicz, Accelerated start-up of a partial nitritation-anammox moving bed biofilm reactor, Biochem. Eng. J., 2019, 145, 83-89.

46 A. Pichel, R. Moreno, M. Figueroa, J. L. Campos, R. Mendez, A. Mosquera-Corral and A. Val del Rio, How to cope with NOB activity and pig manure inhibition in a partial nitritation-anammox process?, Sep. Purif. Technol., 2019, 212, 396-404.

47 Y. Yang, L. Zhang, X. Han, S. Zhang, B. Li and Y. Peng, Determine the operational boundary of a pilot-scale 
single-stage partial nitritation/anammox system with granular sludge, Water Sci. Technol., 2016, 73, 2085-2092.

$48 \mathrm{X}$. Wang and D. Gao, In situ restoration of one-stage partial nitritation-anammox process deteriorated by nitrate buildup via elevated substrate levels, Sci. Rep., 2016, 6, 37-50.

49 D. Kang, Q. Lin, D. Xu, Q. Hu, Y. Li, A. Ding, M. Zhang and P. Zheng, Color characterization of anammox granular sludge: Chromogenic substance, microbial succession and state indication, Sci. Total Environ., 2018, 642, 13201327.

50 L. Miao, G. Yang, T. Tao and Y. Peng, Recent advances in nitrogen removal from landfill leachate using biological treatments - A review, J. Environ. Manage., 2019, 235, 178185.

51 Y. Kimura, K. Isaka, F. Kazama and T. Sumino, Effects of nitrite inhibition on anaerobic ammonium oxidation, Appl. Microbiol. Biotechnol., 2010, 86, 359-365.

52 D. Puyol, J. M. Carvajal-Arroyo, R. Sierra-Alvarez and J. A. Field, Nitrite (not free nitrous acid) is the main inhibitor of the anammox process at common $\mathrm{pH}$ conditions, Biotechnol. Lett., 2014, 36, 547-551.

53 W. Wei, X. Zhou, D. Wang, J. Sun and Q. Wang, Free ammonia pre-treatment of secondary sludge significantly increases anaerobic methane production, Water Res., 2017, 118, 12-19.

54 Y. Zhang, S. He, Q. Niu, W. Qi and Y.-Y. Li, Characterization of three types of inhibition and their recovery processes in an anammox UASB reactor, Biochem. Eng. J., 2016, 109, 212221.

55 S. He, Y. Chen, M. Qin, Z. Mao, L. Yuan, Q. Niu and X. Tan, Effects of temperature on anammox performance and community structure, Bioresour. Technol., 2018, 260, 186195.

56 H. Duan, S. Gao, X. Li, N. H. Ab Hamid, G. Jiang, M. Zheng, X. Bai, P. L. Bond, X. Lu and M. M. Chislett, Improving wastewater management using free nitrous acid (FNA) a review, Water Res., 2019, 11, 53-82.

57 Y. Liu, Q. Niu, S. Wang, J. Ji, Y. Zhang, M. Yang, T. Hojo and Y. Y. Li, Upgrading of the symbiosis of Nitrosomonas and anammox bacteria in a novel single-stage partial nitritation-anammox system: Nitrogen removal potential and Microbial characterization, Bioresour. Technol., 2017, 244, 463-472.

58 Z. Yin, C. E. D. d. Santos, J. G. Vilaplana, D. Sobotka, K. Czerwionka, M. H. R. Z. Damianovic, L. Xie, F. J. F. Morales and J. Makinia, Importance of the combined effects of dissolved oxygen and $\mathrm{pH}$ on optimization of nitrogen removal in anammox-enriched granular sludge, Process Biochem., 2016, 51, 1274-1282.

59 H. Bae, T. Paul, D. Kim and J.-Y. Jung, Specific ANAMMOX activity (SAA) in a sequencing batch reactor: optimization test with statistical comparison, Environ. Earth Sci., 2016, 75, 1452-1460.

60 A. Alinsafi, N. Adouani, F. Béline, T. Lendormi, L. Limousy and $\mathrm{O}$. Sire, Nitrite effect on nitrous oxide emission from denitrifying activated sludge, Process Biochem., 2008, 43, 683-689.
61 Y. Zhou, L. Ganda, M. Lim, Z. Yuan, S. Kjelleberg and W. J. Ng, Free nitrous acid (FNA) inhibition on denitrifying poly-phosphate accumulating organisms (DPAOs), Appl. Microbiol. Biotechnol., 2010, 88, 359-369.

62 Q. Niu, S. He, Y. Zhang, H. Ma, Y. Liu and Y. Y. Li, Process stability and the recovery control associated with inhibition factors in a UASB-anammox reactor with a long-term operation, Bioresour. Technol., 2016, 203, 132-141.

63 H. Ma, Q. Niu, Y. Zhang, S. He and Y. Y. Li, Substrate inhibition and concentration control in an UASBAnammox process, Bioresour. Technol., 2017, 238, 263-272.

64 Y. Zhang, Q. Niu, H. Ma, S. He, K. Kubota and Y. Y. Li, Longterm operation performance and variation of substrate tolerance ability in an anammox attached film expanded bed (AAFEB) reactor, Bioresour. Technol., 2016, 211, 31-40.

65 I. Çelen-Erdem and E. Sağır-Kurt, A pilot-scale study on the partial nitritation-anammox process for treatment of anaerobic sludge digester effluent, Desalin. Water Treat., 2019, 148, 95-101.

66 Q. Guo, C.-C. Yang, J.-L. Xu, H.-Y. Hu, M. Huang, M.-L. Shi and R.-C. Jin, Individual and combined effects of substrate, heavy metal and hydraulic shocks on an anammox system, Sep. Purif. Technol., 2015, 154, 128-136.

67 D. Zhang, R. Vahala, Y. Wang and B. F. Smets, Microbes in biological processes for municipal landfill leachate treatment: Community, function and interaction, Int. Biodeterior. Biodegrad., 2016, 113, 88-96.

68 T. V. Huynh, P. D. Nguyen, T. N. Phan, D. H. Luong, T. T. V. Truong, K. A. Huynh and K. Furukawa, Application of CANON process for nitrogen removal from anaerobically pretreated husbandry wastewater, Int. Biodeterior. Biodegrad., 2019, 136, 15-23.

69 S. Lackner, A. Terada and B. F. Smets, Heterotrophic activity compromises autotrophic nitrogen removal in membraneaerated biofilms: results of a modeling study, Water Res., 2008, 42, 1102-1112.

70 M. Oshiki, H. Satoh and S. Okabe, Ecology and physiology of anaerobic ammonium oxidizing bacteria, Environ. Microbiol., 2016, 18, 2784-2796.

71 D. Guven, A. Dapena, B. Kartal, M. C. Schmid, B. Maas, K. van de Pas-Schoonen, S. Sozen, R. Mendez, H. J. Op den Camp, M. S. Jetten, M. Strous and I. Schmidt, Propionate oxidation by and methanol inhibition of anaerobic ammonium-oxidizing bacteria, Appl. Environ. Microbiol., 2005, 71, 1066-1071.

72 N. Chamchoi, S. Nitisoravut and J. E. Schmidt, Inactivation of ANAMMOX communities under concurrent operation of anaerobic ammonium oxidation (ANAMMOX) and denitrification, Bioresour. Technol., 2008, 99, 3331-3336.

73 M. Jia, C. M. Castro-Barros, M. K. H. Winkler and E. I. P. Volcke, Effect of organic matter on the performance and $\mathrm{N}_{2} \mathrm{O}$ emission of a granular sludge anammox reactor, Environ. Sci.: Water Res. Technol., 2018, 4, 1035-1046.

74 Y. Feng, Y. Zhao, Y. Guo and S. Liu, Microbial transcript and metabolome analysis uncover discrepant metabolic 
pathways in autotrophic and mixotrophic anammox consortia, Water Res., 2018, 128, 402-411.

75 C. Cai, S. Hu, X. Chen, B. J. Ni, J. Pu and Z. Yuan, Effect of methane partial pressure on the performance of a membrane biofilm reactor coupling methane-dependent denitrification and anammox, Sci. Total Environ., 2018, 639, 278-285.

76 S. Q. Ni, J. Y. Ni, D. L. Hu and S. Sung, Effect of organic matter on the performance of granular anammox process, Bioresour. Technol., 2012, 110, 701-705.

77 S. Sheng, B. Liu, X. Hou, Z. Liang, X. Sun, L. Du and D. Wang, Effects of different carbon sources and $\mathrm{C} / \mathrm{N}$ ratios on the simultaneous anammox and denitrification process, Int. Biodeterior. Biodegrad., 2018, 127, 26-34.

78 L. Fu, F. Zhang, Y. N. Bai, Y. Z. Lu, J. Ding, D. Zhou, Y. Liu and R. J. Zeng, Mass transfer affects reactor performance, microbial morphology, and community succession in the methane-dependent denitrification and anaerobic ammonium oxidation co-culture, Sci. Total Environ., 2019, 651, 291-297.

79 E. Torresi, M. Escola Casas, F. Polesel, B. G. Plosz, M. Christensson and K. Bester, Impact of external carbon dose on the removal of micropollutants using methanol and ethanol in post-denitrifying Moving Bed Biofilm Reactors, Water Res., 2017, 108, 95-105.

80 S. Peng, X. Han, F. Song, L. Zhang, C. Wei, P. Lu and D. Zhang, Inhibition of benzene, toluene, phenol and benzoate in single and combined on Anammox activity: implication to the denitrification-Anammox synergy, Biodegradation, 2018, 29, 567-577.

81 L. Lyu, K. Zhang, Z. Li, Y. Ma, T. Chai, Y. Pan, X. Wang, S. Li and T. Zhu, Inhibition of anammox activity by phenol: Suppression effect, community analysis and mechanism simulation, Int. Biodeterior. Biodegrad., 2018, 141, 30-38.

82 S. Ding, J. Wu, M. Zhang, H. Lu, Q. Mahmood and P. Zheng, Acute toxicity assessment of ANAMMOX substrates and antibiotics by luminescent bacteria test, Chemosphere, 2015, 140, 174-183.

83 X. Zhang, Z. Chen, Y. Ma, T. Chen, J. Zhang, H. Zhang, S. Zheng and J. Jia, Impacts of erythromycin antibiotic on Anammox process: Performance and microbial community structure, Biochem. Eng. J., 2019, 143, 1-8.

84 X. Zhang, Z. Chen, Y. Ma, N. Zhang, Q. Pang, X. Xie, Y. Li and J. Jia, Response of Anammox biofilm to antibiotics in trace concentration: Microbial activity, diversity and antibiotic resistance genes, J. Hazard. Mater., 2019, 367, 182-187.

85 Z.-J. Shi, H.-Y. Hu, Y.-Y. Shen, J.-J. Xu, M.-L. Shi and R.-C. Jin, Long-term effects of oxytetracycline (OTC) on the granule-based anammox: Process performance and occurrence of antibiotic resistance genes, Biochem. Eng. J., 2017, 127, 110-118.

86 R.-C. Jin, P. Zheng, Q. Mahmood and B.-L. Hu, Osmotic stress on nitrification in an airlift bioreactor, J. Hazard. Mater., 2007, 146, 148-154.

87 Á. Val del Río, T. da Silva, T. H. Martins, E. Foresti, J. L. Campos, R. Méndez and A. Mosquera-Corral, Partial
Nitritation-Anammox Granules: Short-Term Inhibitory Effects of Seven Metals on Anammox Activity, Water, Air, Soil Pollut., 2017, 228, 439-448.

88 A. Dapena-Mora, I. Fernández, J. L. Campos, A. MosqueraCorral, R. Méndez and M. S. M. Jetten, Evaluation of activity and inhibition effects on Anammox process by batch tests based on the nitrogen gas production, Enzyme Microb. Technol., 2007, 40, 859-865.

89 A. Val Del Rio, A. Pichel, N. Fernandez-Gonzalez, A. Pedrouso, A. Fra-Vazquez, N. Morales, R. Mendez, J. L. Campos and A. Mosquera-Corral, Performance and microbial features of the partial nitritation-anammox process treating fish canning wastewater with variable salt concentrations, J. Environ. Manage., 2018, 208, 112-121.

90 J. Li, P. Qi, R. Li, J. Wang and D. Wang, Carbon and nitrogen removal through "Candidatus Brocadia sinica"-dominated simultaneous anammox and denitrification (SAD) process treating saline wastewater, Biochem. Eng. J., 2018, 140, 7276.

91 C. H. Ge, Y. Dong, H. Li, Q. Li, S. Q. Ni, B. Gao, S. Xu, Z. Qiao and S. Ding, Nitritation-anammox process - A realizable and satisfactory way to remove nitrogen from high saline wastewater, Bioresour. Technol., 2019, 275, 86-93.

92 X. Li, Y. Yuan, Y. Yuan, Z. Bi, X. Liu, Y. Huang, H. Liu, C. Chen and S. Xu, Effects of salinity on the denitrification efficiency and community structure of a combined partial nitritation- anaerobic ammonium oxidation process, Bioresour. Technol., 2018, 249, 550-556.

93 L. Quartaroli, L. C. Silva, C. M. Silva, H. S. Lima, S. O. de Paula, V. M. de Oliveira, S. d. S. M. de Cassia, M. C. Kasuya, M. P. de Sousa, A. P. Torres, R. S. Souza, J. P. Bassin and C. C. da Silva, Ammonium removal from high-salinity oilfield-produced water: assessing the microbial community dynamics at increasing salt concentrations, Appl. Microbiol. Biotechnol., 2017, 101, 859-870.

94 Z. Z. Zhang, Y. X. Ji, Y. F. Cheng, L. Z. Xu and R. C. Jin, Increased salinity improves the thermotolerance of mesophilic anammox consortia, Sci. Total Environ., 2018, 644, 710-716.

95 M. J. García-Ruiz, A. Castellano-Hinojosa, J. González-López and F. Osorio, Effects of salinity on the nitrogen removal efficiency and bacterial community structure in fixed-bed biofilm CANON bioreactors, Chem. Eng. J., 2018, 347, 156164.

96 C. Kalkan Aktan, A. E. Uzunhasanoglu and K. Yapsakli, Speciation of nickel and zinc, its short-term inhibitory effect on anammox, and the associated microbial community composition, Bioresour. Technol., 2018, 268, 558-567.

97 H. Chen, J.-J. Yu, X.-Y. Jia and R.-C. Jin, Enhancement of anammox performance by $\mathrm{Cu}(\mathrm{II}), \mathrm{Ni}(\mathrm{II})$ and $\mathrm{Fe}(\mathrm{III})$ supplementation, Chemosphere, 2014, 117, 610-616.

98 X. Cao, H. Cao, Y. Sheng, Y. Xie, K. Zhang, Y. Zhang and J. C. Crittenden, Mechanisms of $\mathrm{Cu} 2+$ migration, recovery and detoxification in $\mathrm{Cu} 2+-$,-containing 
wastewater treatment process with anaerobic granular sludge, Environ. Technol., 2014, 35, 1956-1961.

99 J. E. Aston, B. M. Peyton, B. D. Lee and W. A. Apel, Effects of ferrous sulfate, inoculum history, and anionic form on lead, zinc, and copper toxicity to Acidithiobacillus caldus strain BC13, Environ. Toxicol. Chem., 2010, 29, 2669-2675.

100 J. J. Xu, Z. Z. Zhang, Q. Q. Chen, Z. Q. Ji, Y. H. Zhu and R. C. Jin, The short- and long-term effects of $\mathrm{Mn}(2+)$ on biogranule-based anaerobic ammonium oxidation (anammox), Bioresour. Technol., 2017, 241, 750-759.

101 G. Li, D. Puyol, J. M. Carvajal-Arroyo, R. Sierra-Alvarez and J. Field, Inhibition of anaerobic ammonium oxidation by heavy metals, J. Chem. Technol. Biotechnol., 2015, 90, 830837.

102 C. Yu, Y. X. Song, L. Y. Chai, C. S. Duan, C. J. Tang, M. Ali and C. Peng, Comparative evaluation of short-term stress of $\mathrm{Cd}(\mathrm{II}), \mathrm{Hg}(\mathrm{II}), \mathrm{Pb}(\mathrm{II}), \mathrm{As}(\mathrm{III})$ and $\mathrm{Cr}(\mathrm{VI})$ on anammox granules by batch test, J. Biosci. Bioeng., 2016, 122, 722-729.

103 D. Wu, Q. Zhang, W.-J. Xia, Z.-J. Shi, B.-C. Huang, N.-S. Fan and R.-C. Jin, Effect of divalent nickel on the anammox process in a UASB reactor, Chemosphere, 2019, 226, 934944.

104 G.-F. Yang, W.-M. Ni, K. Wu, H. Wang, B.-E. Yang, X.-Y. Jia and R.-C. Jin, The effect of $\mathrm{Cu}(\mathrm{II})$ stress on the activity, performance and recovery on the Anaerobic AmmoniumOxidizing (Anammox) process, Chem. Eng. J., 2013, 226, 39-45.

105 Z. Bi, S. Qiao, J. Zhou, X. Tang and Y. Cheng, Inhibition and recovery of Anammox biomass subjected to short-term exposure of $\mathrm{Cd}, \mathrm{Ag}, \mathrm{Hg}$ and $\mathrm{Pb}$, Chem. Eng. J., 2014, 244, 89-96.

106 M. Kumar and J. G. Lin, Co-existence of anammox and denitrification for simultaneous nitrogen and carbon removal-Strategies and issues, J. Hazard. Mater., 2010, 178, 1-9.

107 S. Liu, F. Yang, Z. Gong, F. Meng, H. Chen, Y. Xue and K. Furukawa, Application of anaerobic ammoniumoxidizing consortium to achieve completely autotrophic ammonium and sulfate removal, Bioresour. Technol., 2008, 99, 6817-6825.

108 F. Zhang, Y. Peng, S. Wang, Z. Wang and H. Jiang, Efficient step-feed partial nitrification, simultaneous Anammox and denitrification (SPNAD) equipped with real-time control parameters treating raw mature landfill leachate, $J$. Hazard. Mater., 2019, 364, 163-172.

109 M. Kumar and J.-G. Lin, Co-existence of anammox and denitrification for simultaneous nitrogen and carbon removal-strategies and issues, J. Hazard. Mater., 2010, 178, 1-9.

110 J. Li, W. Zhu, H. Dong and D. Wang, Performance and kinetics of ANAMMOX granular sludge with $\mathrm{pH}$ shock in a sequencing batch reactor, Biodegradation, 2017, 28, 245259.

111 M. Tomaszewski, G. Cema and A. Ziembinska-Buczynska, Influence of temperature and $\mathrm{pH}$ on the anammox process: A review and meta-analysis, Chemosphere, 2017, 182, 203-214.
112 Y. Sun, S. Zhou, H. Li and F. Qin, Start-up of ANAMMOXdenitrification reactor and effect of organic loading on its performance of synergistic interaction, J. Chem. Ind. Eng., 2009, 60, 2596-2602.

113 M. Strous, E. Pelletier, S. Mangenot, T. Rattei, A. Lehner, M. W. Taylor, M. Horn, H. Daims, D. Bartol-Mavel and P. Wincker, Deciphering the evolution and metabolism of an anammox bacterium from a community genome, Nat. Commun., 2006, 440, 790.

114 S. Lackner, E. M. Gilbert, S. E. Vlaeminck, A. Joss, H. Horn and M. C. van Loosdrecht, Full-scale partial nitritation/ anammox experiences-an application survey, Water Res., 2014, 55, 292-303.

115 L. Cheng, X. Li, X. Lin, L. Hou, M. Liu, Y. Li, S. Liu and $\mathrm{X}$. $\mathrm{Hu}$, Dissimilatory nitrate reduction processes in sediments of urban river networks: Spatiotemporal variations and environmental implications, Biochim. Biophys. Acta, 2016, 219, 545-554.

116 E. M. Gilbert, S. Agrawal, T. Schwartz, H. Horn and S. Lackner, Comparing different reactor configurations for Partial Nitritation/Anammox at low temperatures, Water Res., 2015, 81, 92-100.

117 T. Lotti, R. Kleerebezem and M. Van Loosdrecht, Effect of temperature change on anammox activity, Biotechnol. Bioeng., 2015, 112, 98-103.

118 N. Byrne, M. Strous, V. Crepeau, B. Kartal, J. L. Birrien, M. Schmid, F. Lesongeur, S. Schouten, A. Jaeschke, M. Jetten, D. Prieur and A. Godfroy, Presence and activity of anaerobic ammonium-oxidizing bacteria at deep-sea hydrothermal vents, ISME J., 2009, 3, 117-123.

119 D. W. Gao and Y. Tao, Versatility and application of anaerobic ammonium-oxidizing bacteria, Appl. Microbiol. Biotechnol., 2011, 91, 887-894.

120 Z. Zheng, J. Li, J. Ma, J. Du, W. Bian, Y. Li, Y. Zhang and B. Zhao, Nitrogen removal via simultaneous partial nitrification, anammox and denitrification (SNAD) process under high DO condition, Biodegradation, 2016, 27, 195-208.

121 S. Lackner, C. Lindenblatt and H. Horn, 'Swinging ORP'as operation strategy for stable reject water treatment by nitritation-anammox in sequencing batch reactors, Chem. Eng. J., 2012, 180, 190-196.

122 Z. Wang, L. Zhang, F. Zhang, H. Jiang, S. Ren, W. Wang and Y. Peng, Enhanced nitrogen removal from nitrate-rich mature leachate via partial denitrification (PD)-anammox under real-time control, Bioresour. Technol., 2019, 121, 615.

123 H. Kim, A. Ogram and H.-S. Bae, Nitrification, Anammox and Denitrification along a Nutrient Gradient in the Florida Everglades, Wetlands, 2016, 37, 391-399.

124 J. Yang, J. Trela, E. Plaza, O. Wahlberg and E. Levlin, Oxidation-reduction potential (ORP) as a control parameter in a single-stage partial nitritation/anammox process treating reject water, J. Chem. Technol. Biotechnol., 2016, 91, 2582-2589.

125 R. E. Murray, L. L. Parsons and M. S. Smith, Aerobic and anaerobic growth of rifampin-resistant denitrifying 
bacteria in soil, Appl. Microbiol. Biotechnol., 1990, 56, 323328.

126 Y. Miao, Y. Peng, L. Zhang, B. Li, X. Li, L. Wu and S. Wang, Partial nitrification-anammox (PNA) treating sewage with intermittent aeration mode: effect of influent $\mathrm{C} / \mathrm{N}$ ratios, Chem. Eng. J., 2018, 334, 664-672.

127 T. Liu, B. Ma, X. Chen, B.-J. Ni, Y. Peng and J. Guo, Evaluation of mainstream nitrogen removal by simultaneous partial nitrification, anammox and denitrification (SNAD) process in a granule-based reactor, Chem. Eng. J., 2017, 327, 973-981.

128 J. R. Vázquez-Padín, M. Figueroa, I. Fernández, A. Mosquera-Corral, J. Campos and R. Mendez, Posttreatment of effluents from anaerobic digesters by the Anammox process, Water Sci. Technol., 2009, 60, 11351143.

129 B. Wang, Y. Peng, Y. Guo, Y. Yuan, M. Zhao and S. Wang, Impact of partial nitritation degree and $\mathrm{C} / \mathrm{N}$ ratio on simultaneous Sludge Fermentation, Denitrification and Anammox process, Bioresour. Technol., 2016, 219, 411-419.

130 M. S. Jetten, M. Strous, K. T. Van de Pas-Schoonen, J. Schalk, U. G. van Dongen, A. A. van de Graaf, S. Logemann, G. Muyzer, M. C. van Loosdrecht and J. G. Kuenen, The anaerobic oxidation of ammonium, FEMS Microbiol. Rev., 1998, 22, 421-437.

131 D. Choi, S. Cho and J. Jung, Key operating parameters affecting nitrogen removal rate in single-stage deammonification, Chemosphere, 2018, 207, 357-364.

132 R. Du, S. Cao, B. Li, H. Zhang, S. Wang and Y. Peng, Synergy of partial-denitrification and anammox in continuously fed upflow sludge blanket reactor for simultaneous nitrate and ammonia removal at room temperature, Bioresour. Technol., 2019, 274, 386-394.

133 R. Du, S. Cao, B. Li, S. Wang and Y. Peng, Simultaneous domestic wastewater and nitrate sewage treatment by DEnitrifying AMmonium OXidation (DEAMOX) in sequencing batch reactor, Chemosphere, 2017, 174, 399407.

134 P. Jin, B. Li, D. Mu, X. Li and Y. Peng, High-efficient nitrogen removal from municipal wastewater via twostage nitritation/anammox process: Long-term stability assessment and mechanism analysis, Bioresour. Technol., 2019, 271, 150-158.

135 Z. Zheng, S. Huang, W. Bian, D. Liang, X. Wang, K. Zhang, X. Ma and J. Li, Enhanced nitrogen removal of the simultaneous partial nitrification, anammox and denitrification (SNAD) biofilm reactor for treating mainstream wastewater under low dissolved oxygen (DO) concentration, Bioresour. Technol., 2019, 283, 213-220.

136 D. Wang, T. Li, K. Huang, X. He and X.-X. Zhang, Roles and correlations of functional bacteria and genes in the start-up of simultaneous anammox and denitrification system for enhanced nitrogen removal, Sci. Total Environ., 2019, 655, 1355-1363.

137 M. Raudkivi, I. Zekker, E. Rikmann, P. Vabamäe, K. Kroon and T. Tenno, Nitrite inhibition and limitation-the effect of nitrite spiking on anammox biofilm, suspended and granular biomass, Water Sci. Technol., 2016, 75, 313-321.

138 S. Jenni, S. E. Vlaeminck, E. Morgenroth and K. M. Udert, Successful application of nitritation/anammox to wastewater with elevated organic carbon to ammonia ratios, Water Res., 2014, 49, 316-326.

139 T. Lotti, R. Kleerebezem, J. Abelleira-Pereira, B. Abbas and M. Van Loosdrecht, Faster through training: the anammox case, Water Res., 2015, 81, 261-268.

140 Z. Zhou, X. Lin, F. Wang, C. Gu, J. Shen, Y. Yuan and R. Jin, Removal of Nitrogen from Alcohol Wastewater by PNANAMMOX, Environ. Sci., 2017, 38, 3377-3384.

141 Q. Wang, Y. Wang, J. Lin, R. Tang, W. Wang, X. Zhan and Z.-H. Hu, Selection of seeding strategy for fast start-up of Anammox process with low concentration of Anammox sludge inoculum, Bioresour. Technol., 2018, 268, 638-647.

142 J. Zhang, Y. Miao, Q. Zhang, Y. Sun, L. Wu and Y. Peng, Mechanism of stable sewage nitrogen removal in a partial nitrification-anammox biofilm system at low temperatures: microbial community and EPS analysis, Bioresour. Technol., 2019, 12, 24-59.

143 X. Yin, S. Qiao, J. Zhou and X. Tang, Fast start-up of the anammox process with addition of reduced graphene oxides, Chem. Eng. J., 2016, 283, 160-166.

144 P. Jara-Muñoz, V. Guzmán-Fierro, C. Arriagada, V. Campos, J. L. Campos, J. J. Gallardo-Rodríguez, K. Fernández and M. Roeckel, Low oxygen start-up of partial nitrification-anammox process: mechanical or gas agitation?, J. Chem. Technol. Biotechnol., 2019, 94, 475-483.

145 X. Huang, K. Urata, Q. Wei, Y. Yamashita, T. Hama and Y. Kawagoshi, Fast start-up of partial nitritation as pretreatment for anammox in membrane bioreactor, Biochem. Eng. J., 2016, 105, 371-378.

146 C. Glass and J. Silverstein, Denitrification kinetics of high nitrate concentration water: $\mathrm{pH}$ effect on inhibition and nitrite accumulation, Water Res., 1998, 32, 831-839.

147 W. Qian, B. Ma, X. Li, Q. Zhang and Y. Peng, Long-term effect of $\mathrm{pH}$ on denitrification: High $\mathrm{pH}$ benefits achieving partial-denitrification, Bioresour. Technol., 2019, 278, 444-449.

148 B. Cui, X. Liu, Q. Yang, J. Li, X. Zhou and Y. Peng, Achieving partial denitrification through control of biofilm structure during biofilm growth in denitrifying biofilter, Bioresour. Technol., 2017, 238, 223-231.

149 J. Ji, Y. Peng, B. Wang and S. Wang, Achievement of high nitrite accumulation via endogenous partial denitrification (EPD), Bioresour. Technol., 2017, 224, 140146.

150 D. Wang, Y. He and X. X. Zhang, A comprehensive insight into the functional bacteria and genes and their roles in simultaneous denitrification and anammox system at varying substrate loadings, Appl. Microbiol. Biotechnol., 2019, 103, 1523-1533.

151 R. R. Nair, P. B. Dhamole, S. S. Lele and S. F. D'Souza, Biological denitrification of high strength nitrate waste using preadapted denitrifying sludge, Chemosphere, 2007, 67, 1612-1617. 